EXAMINING THE EQUITABILITY OF PUBLIC TRANSIT POLICIES IN MONTRÉAL, TORONTO, AND VANCOUVER

by

Aaron Robert William Johnston

Bachelor of Arts (Honours), Political Science

Saint Mary’s University, 2017

A Major Research Paper
presented to Ryerson University

in partial fulfillment of the

requirements for the degree of

Master of Arts in the program of

Public Policy and Administration

Toronto, Ontario, Canada, 2019

(C) Aaron Robert William Johnston, 2019 


\section{Author's Declaration for Electronic Submission of a MRP}

I hereby declare that I am the sole author of this MRP. This is a true copy of the MRP, including any required final revisions.

I authorize Ryerson University to lend this MRP to other institutions or individuals for the purpose of scholarly research.

I further authorize Ryerson University to reproduce this MRP by photocopying or by other means, in total or in part, at the request of other institutions or individuals for the purpose of scholarly research.

I understand that my MRP may be made electronically available to the public. 


\title{
EXAMINING THE EQUITABILITY OF PUBLIC TRANSIT POLICIES IN MONTRÉAL, TORONTO, AND VANCOUVER
}

Aaron Robert William Johnston

Master of Arts: Public Policy and Administration

Ryerson University, 2019

\begin{abstract}
This major research paper (MRP) will provide a comparative analysis of the equity policies within the transportation networks of three major Canadian cities: Montréal, Toronto, and Vancouver. During the course of researching this MRP, it became evident that Vancouver's TransLink transit system would be a useful model to utilize as the basis of this comparative study, due to its extensive equity policies, and funding of its transit network, in relation to the transportation systems of Toronto and Montréal. In addition, TransLink has implemented these equitable measures without being mandated to do so by the Government of British Columbia. Vancouver's transit policies employ a number of comprehensive equity measures, which were examined using two theoretical lenses of horizontal and vertical equity, and these were then compared to Montréal's Société de Transport and the Toronto Transit Commission (TTC). These lenses aid in providing a deeper understanding of the policies employed by these transportation networks; as well as affording a basis for the comparative analysis.
\end{abstract}




\section{Acknowledgements}

I would like to thank a number of individuals who helped me throughout the development of this MRP. I would first like to extend my profound gratitude to my supervisor, Dr. Duncan MacLellan, whose expert commentary and research guidance have been critical through the development of this MRP. Additionally, I would like to thank my second reader, Dr. Neil Thomlinson for conducting an in-depth review during the refinement of this MRP. Lastly, I

would like to thank my family and friends for their emotional support and guidance through this academic endeavor. 


\section{Table of Contents}

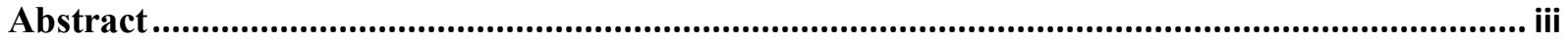

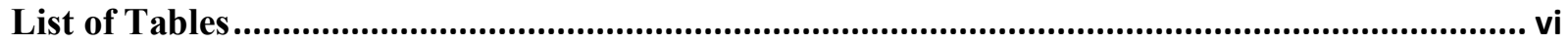

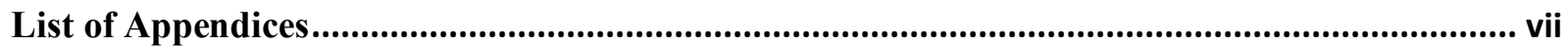

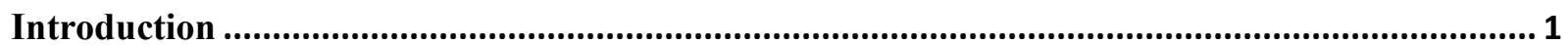

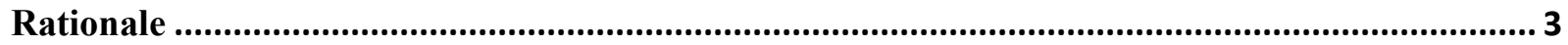

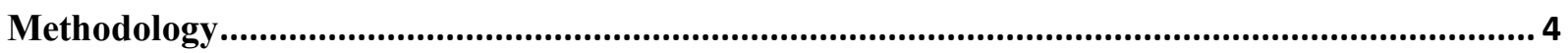

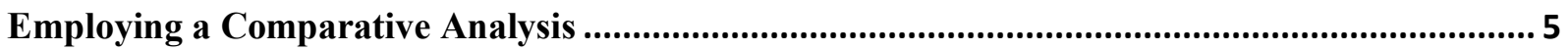

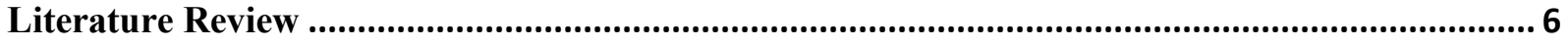

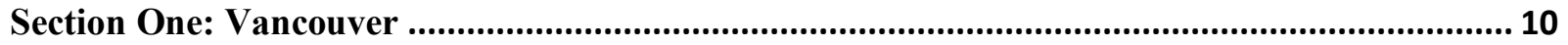

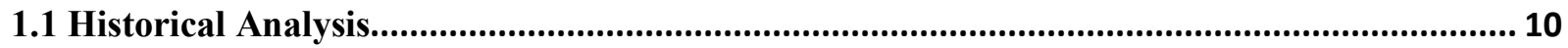

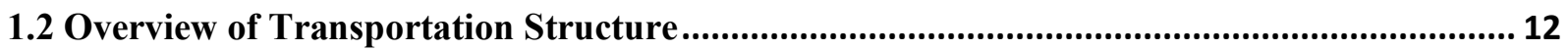

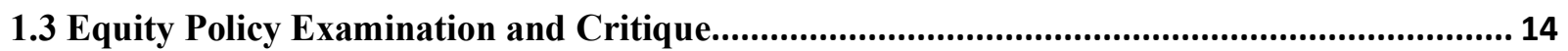

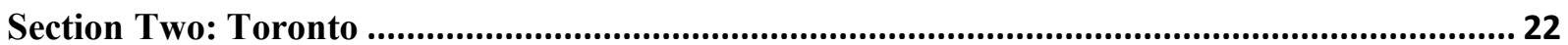

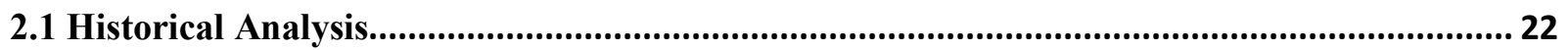

2.2 Overview of Transportation Structure ..................................................................................... 25

2.3 Equity Policy Examination and Critique.................................................................................. 29

2.3.1 Equity Policy Cross-Examination: Toronto and Vancouver ....................................................... 39

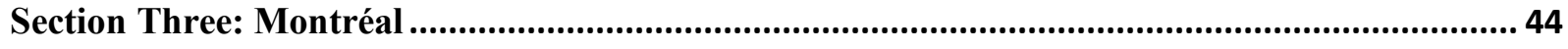

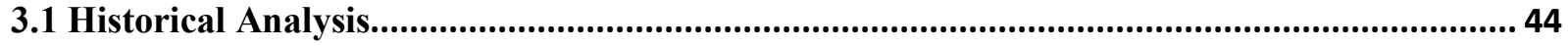

3.2 Overview of Transportation Structure ........................................................................................ 46

3.3 Equity Policy Examination and Critique................................................................................... 48

3.3.1 Equity Policy Cross-Examination: Montréal and Vancouver.................................................... 52

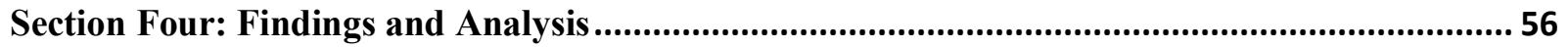

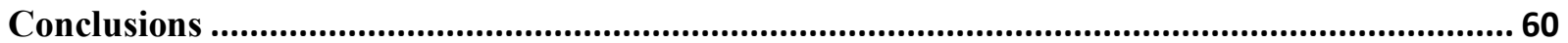

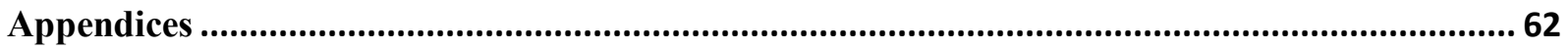

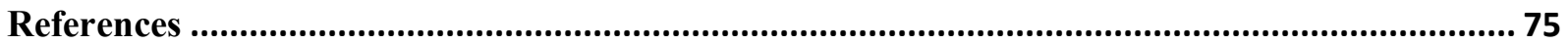




\section{List of Tables}

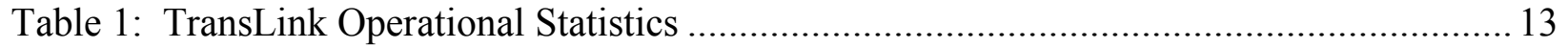

Table 2: Equity Comparison: TransLink ................................................................... 14

Table 3: TransLink fares ............................................................................................. 16

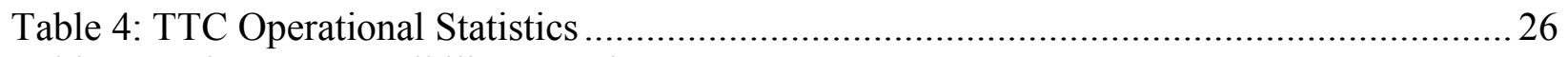

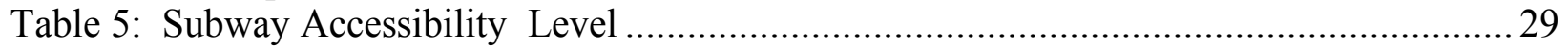

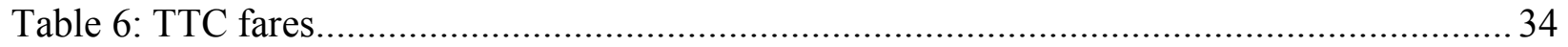

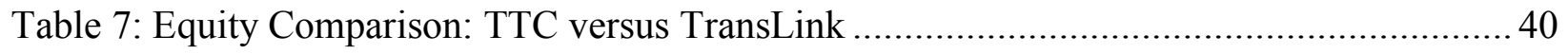

Table 8: Fare Comparison: TTC versus TransLink ................................................... 42

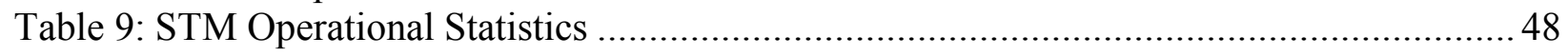

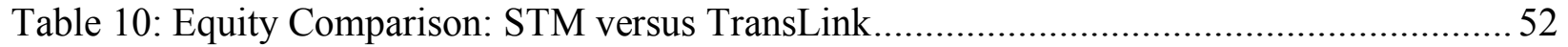

Table 11: Fare Comparison: STM versus TransLink ....................................................... 54

Table 12: Equity Policy Comparison: TransLink versus TTC \& STM..................................59 


\section{List of Appendices}

Appendix A: 2019-2013 TTC Multi- Year Accessibility Plan.............................57

Appendix B: TransLink Zone Fare Map.......................................69 


\section{Introduction}

This major research paper (MRP) compares Vancouver's transit network with those of Toronto and Montréal, focusing specifically on the respective cities' equity policies. The main goal of this major research paper is to determine the level of equitability in the public transportation networks of three Canadian cities: The MRP will employ Vancouver's transit network, TransLink, as a model transportation network to examine the equitability of the transportation systems of Toronto [the Toronto's Transit Commission (TTC)] and Montréal [Société de transport (STM)]. During the course of researching this MRP, it became evident that Vancouver's transit system would be a useful model to utilize as a basis for analysis in this comparative study, due to its extensive equity policies and funding in relation to the transportation systems of Toronto and Montréal. Moreover, TransLink has implemented these equitable measures without being mandated to do so by provincial legislation. The next most equitable transit network is Toronto, followed by Montreal. This is because the Toronto Transit Commission employs a more equitable fare structure and its barrier reduction measures are more comprehensive than those of the STM.

Vancouver, Toronto, and Montréal are the most urbanized cities in Canada because of continued growth in population and increasing infrastructure demands to support this continued expansion. For these reasons, they are viable to analyze for this MRP. In 2017, the populations of the three cities were: Vancouver, 600,000; Montréal, 1,600,000 and Toronto, 2,600,000 (World Population Review, 2019). Transportation is vital to the effective functioning of a city because it provides people with the means to travel to work, access public services, and go about their daily lives. As people become increasingly aware of the environmental impacts of automobiles, public transportation is becoming a more viable option for many citizens. However, as this MRP will 
discuss more fully, these cities do not afford all people the same opportunities to access their transportation network, due to inequities. According to Kramer and Goldstein, "equity refers to the role that public infrastructure, in this case transit networks, plays in making public goods, in this case mobility and access, more equally available to all people" (2015, p. 25). These inequities take different forms such as economic, structural, and political barriers that create an increasingly inequitable public transit system. The concept of equitability, in relation to public transportation, is frequently analyzed through the theoretical lenses of horizontal and vertical equity (Camporealeet al., 2017). Camporeale et al. (2017) define "horizontal equity" as benefits being evenly distributed among a group of people with similar needs; and "vertical equity" as aid being dispersed among groups with different needs based upon those people who need it the most. The notion of equity, in this context, will form an integral part of this paper. 


\section{Rationale}

There is an abundance of literature that analyzes transportation equity; however, there is a lack of comparative literature analyzing transportation equity in the Canadian context. Thus, this MRP will contribute to the growing scholarship on promoting transit equity in Canada. In the examination of the equitability of these cities' public transportation networks, this MRP will provide an investigation into the policy outcomes that would make transportation in these cities more equitable. The MRP will address the following research questions:

- How do the cities of Vancouver, Toronto, and Montréal define equitability, in relation to transit?

- What types of obstacles do these three cities face in implementing equitable transit systems?

- What current strategies have been taken to ensure more equitable transportation in these three cities? 


\section{Methodology}

This MRP will employ a comparative qualitative approach, by researching and illustrating transportation academic scholarship and government documents (speeches, budgets, transportation equity policies), to provide an in-depth analysis of the level of equitability, effectivity, and type of equity implemented within TransLink, the TTC and STM systems. These cities are appropriate to utilize in this comparative approach because they represent geographic diversity within Canada in terms of their populations' transit networks, political structures, and the socioeconomic status of their citizens. Politically, Montreal and Vancouver are unique because there are municipal parties, unlike Toronto, which has no formal political parties at the municipal level.

The methodology of this MRP is also informed by two dominant theoretical lenses utilized in the field of public transportation that pertain to equality: horizontal equity and vertical equity (Camporealeet al., 2017). This MRP will utilize both, but with more emphasis on vertical equity.

This MRP will be divided into three main sections, one for each city. In each section, there will be a brief historical and structural overview of the transportation network, an analysis of the equitably of the system, and a comparative analysis between the model city, in this case Vancouver, and the equity policies of the test cities, in this case Montréal and Toronto. The first section will focus on Vancouver, but it will not have a comparative analysis because this will be discussed in the two succeeding sections. 


\section{Employing a Comparative Analysis}

To expand a bit more on why a comparative approach was selected for this MRP, it was thought this this would provide a richer analysis of the transportation systems in Toronto, Montréal, and Vancouver due to the benefits of this methodological approach. Denters and Mossberger (2006) detail that a comparative method allows researchers to differentiate between variables by grouping similar variables and isolating dissimilar variables. Bryman and Bell (2016) argue that the benefit of utilizing a comparative analysis is the extrapolation of theories

from the identification of the similarities and differences of analyzed variables. Cui, Boisjoly, ElGeneidy, and Levinson (2019) establish the case for utilizing Montréal, Toronto and Vancouver in a comparative study. These three cities are beneficial to use in a comparative study because they are similar in terms of their metropolitan area and population size (Curiet al., 2019). Cuiet al.'s study examined and assessed the transportation accessibility of commute times between different socio-economic groups within Montréal, Toronto, and Vancouver (Curet al., 2019). 


\section{Literature Review}

Scholarship gathered to examine the Toronto Transit Commission (TTC), Société de Transport de Montréal (STM) and TransLink, will assist in answering the three research questions. In analyzing the equitability of the transportation networks, two dominant theoretical lenses, horizontal and vertical equity (within the field of transportation studies) are employed in the analysis of the equity policies of the TTC, STM, and TransLink. Camporeale, Caggiani, Fonzone and Ottomanelli (2017) define and explain these two equity lenses, and provide the context in which these lenses can be applied. As noted earlier, horizontal equity is when benefits and subsidies are evenly distributed between groups of people; whereas, vertical equity refers to benefits distributed among disadvantaged groups (Camporealeet al., 2017). Concerning Toronto's public transportation network, Hertel, Keil, and Collens (2016) provide an analysis of the vertical and horizontal equity policies employed by the TTC. Camporealeet al. (2017) and Hertel's (2016) work provide an in-depth understanding of the equitability, structure, and intent of the policies provided by the TTC.

Utilizing these two theoretical lenses aids in a comparative analysis of transit networks with regard to the identification of their different cost and benefit designs, whether it be vertically economic or horizontal and universal. For example, the TTC employs more vertical and horizontal equity policies than the STM; therefore, the application of a comparative analysis provides an effective method for this MRP to analyze the equitability of these three transit networks.

A number of scholars explore how employing a comparative method can be advantageous as a mode of analysis. Denters and Mossberger (2006) provide an explanation of how a comparative method is employed, while Braymen and Bell (2016) highlight the 
advantages of utilizing a comparative method. The work of Cui, Boisjoly, El-Geneidy, and Levinson (2019) work is timely and very recently published. Moreover, it sets a precedent for utilizing a comparative study in the analysis of the transportation networks in Toronto, Montréal, and Vancouver.

Radford, Sinclair, Filey, and Derrible provide an analysis of the historical developments of Toronto's transportation networks. Both Radford and Sinclair explain the origins of transportation networks in Toronto. Radford (2015) explains that the first transportation network, the Toronto Street Railway Company (TSRC), employed hundreds of people in the city, and operated the horse-drawn streetcars as a mode of transportation. Sinclair (1891) provides an overview of the TSRC's failure and mismanagement and explains that there was a brief period when transportation went under public ownership in Toronto. Filey (1996) and Derrible (2012) provide an examination of Toronto's transit networks in the $20^{\text {th }}$ century. Filey explains that the forerunner to the TTC was established in the 1920s, due to civic unrest over the poor quality of service that private companies provided. Derrible's work adds to the MRP by providing an overview of the development of the first subway system in Toronto and a timeline of the changes and upgrades that occurred with the underground system in the 1940s through to the 1980s.

The scholarship of Hertel, Keil and Collens; Varghese; and Hulchanski provide an overview of the equitability and/or equity policies of transportation within Toronto. Hertel et al. (2016) demonstrate how some of the equity policies employed by the TTC are horizontal. For example, in a study on student discounts, they conclude that discounts are available to all students, even wealthy students. Varghese (2018) provides an examination of "Neighbourhood Improvement Areas" that explores how immigrants and people of lower socioeconomic backgrounds who occupy "neighbourhood improvement areas" experience barriers to 
transportation, specifically the subway system. As an example, Varghese identifies that individuals who live in these underserviced areas experience longer wait times. Varghese's arguments are supported in Hulchanski's 2006 study, which reported that individuals from lower socioeconomic backgrounds experience more barriers in terms of distance to subway stations than wealthy individuals. He concludes this by geographically compartmentalizing Torontonians by income and their distance to subway stations. Hulchanski's work provides contextualization for this MRP concerning the levels of socioeconomic disparities disadvantaged individuals experience when accessing the subway network in Toronto.

Veilleux (1996), Gilbert \& Poitras (2015) provide an historical overview of Montréal's transportation networks. The work of Veilleux (1996) is crucial to the understanding of the origins of Montréal's transportation network. He outlines that the first mode of transportation in Montréal was the tramway system which operated using a horse pulling a tramcar. Gilbert and Poitras (2015) provide context to the tumultuous relationship that evolved between the private transportation providers, the City of Montreal and the Provincial Government in Québec, and how the network eventually became publicly owned.

There is limited scholarship analysing transportation in Vancouver. Two notable scholars who provide a historical analysis of transportation in Vancouver are Meligrana and Wales. Meligrana's (1999) work is integral to understanding the evolution of transportation in Vancouver. He provides an analysis of the modes of transportation in the late $19^{\text {th }}$ to the late $20^{\text {th }}$ centuries, and explains the monopolistic companies like the British Columbia Electric Railway Company and its poor management of transit operations led to its eventual expropriation by the British Columbia Government (Meligrana, 1999). Wales (2008) explains the formation and the complexities of the transportation company TransLink. TransLink is a multifaceted cooperation, 
which has other transportation companies that report to it as well. In addition, TransLink can raise its own funds through taxation and reports to multiple municipalities. 


\section{Section One: Vancouver}

\subsection{Historical Analysis}

Meligrana (1999) provides an extensive historical analysis of the modes of transportation in the Vancouver area that outlines that public transportation started out in Vancouver under a private model with the establishment of the British Columbia Electric Railway Company (BCER) (Meligrana, 1999) The company was established in 1897 and held a monopoly over Vancouver's public transportation until the mid 20th century (Meligrana, 1999). When the company first opened, its entire system was comprised of six streetcars, which ran along 9.6 kilometers of track (TransLink, History, 2019). Streetcars continued to be the dominant mode of transportation until shortly after the Second World War (Meligrana, 1999). BCER experienced financial hardship in the postwar era and found it too costly to upgrade its streetcar system, so the company decided to upgrade its transit network to buses and trolleys (Meligrana, 1999). The Government of British Columbia expropriated BCER in the early 1960s, and it became a crown corporation, which underwent a name change to BC Hydro (Meligrana, 1999). At that time, BC Hydro supplied power along with transportation; funding from generating power was used to operate the public transportation system (Meligrana, 1999). In the 1970s, the BC Government allocated control of public transportation to a new agency, the Bureau of Transit Services; however, bus services at the time continued to be under the control of BC Hydro (Meligrana). Major changes to public transit occurred in the 1980s with the enactment of the Urban Transportation Authority Act, which compartmentalized transportation responsibilities into three categories: first, the consortium of municipalities in and around Vancouver were allocated the power to set fare prices and service levels; second, bus operations were allotted to a newly formed crown cooperation, the Metro Transit Operating Company (MTOC); and, third, the 
Urban Transit Authority (UTA) was given the authority to lease buses and operators (Meligrana, 1999). Another major development was the allotment of taxation powers to municipalities for transportation funding under the Urban Transit Authority Act (Meligrana, 1999). Bus service underwent two more name changes: first in 1982, when the UTA changed its name to BCTransit, and another in 1999, when BC Transit became the Coast Mountain Bus Company (CMBC) (Meligrana, 1999; Wales, 2008).

The SkyTrain is another mode of transportation in the Vancouver transportation system that was incorporated in the 1980s. The SkyTrain is a driverless, rapid transit system that was built as a main feature of the 1986 World Exposition (TransLink, History of SkyTrain, 2019). These Expositions are global events where the aim is to showcase infrastructure (Bureau International des Expositions, About, 2019). The first train line was called the Expo-line after the World Exposition. Eighteen years later, two other lines were incorporated: the Millennium Line (M-Line) and the Canada Line (TransLink, History of SkyTrain, 2019). The M-Line opened with two stations in 2002 and was completed with another 13 stations in 2006 (TransLink, History of SkyTrain, 2019). The Canada Line opened in 2009 in preparation for the 2010 Winter Olympics (TransLink, History of SkyTrain, 2019). Finally, there was an extension to the M-Line, the Millennium Line Evergreen Extension, which began operations in 2016 (TransLink, History of SkyTrain, 2019).

The Seabus service was started in 1977 and provides transportation between the municipalities of Vancouver and North Vancouver (Wales, 2008). Initially the service had two ferries, however a third was added in 2009 in preparation for the 2010 Olympics (Wales, 2008; TransLink Regional Transportation Snapshot 2017). Wales (2008) notes that the Seabus service is a popular choice, as the passenger count reached nearly 100-million passengers by 2007. 
A major development in public transportation in Vancouver and the Greater Vancouver Regional District (GVRD) was the creation, in 1999, of the Greater Vancouver Transportation Authority, knows as TransLink (Wales, 2008). The creation TransLink was in response to concerns about the high number of vehicles on roads, which caused systemic traffic congestion that impeded the efficient movement of people and goods, as well as caused environmental degradation from car emissions. Wales (2008) claims that TransLink is the first of its kind in an international context, due to its unique multi-modal oversight functions of the agency. The creation of TransLink was the result of negotiations between the British Columbia government and the GRVD municipalities, which advocated to the $\mathrm{BC}$ government for a regional solution to help resolve traffic congestion.

\subsection{Overview of Transportation Structure}

TransLink, also referred to as the South Coast British Columbia Transportation Authority (SCBCTA) is a regional transportation authority governed by 21 municipalities through a Mayors Council and the TransLink Board of Directors (TransLink, Governance Model, 2019). The Council of Mayors is in charge of long-term planning, approving investment plans, and overseeing the sale of assets within TransLink (TransLink, Governance Model, 2019). The Council also appoints the TransLink Board of Directors which is responsible for approving the operating budget, publishing annual reports and also contributing to the long-term planning of TransLink (TransLink, Governance Model, 2019). The Province of British Columbia is responsible for the laws that govern the SCBCTA which is regulated by the South Coast British Columbia Authority Act (TransLink, Governance Model, 2019). The Province is also responsible for approving some of the people who sit on the TransLink Board of Directors (TransLink, Governance Model, 2019). 
TransLink is made up of a variety of transportation companies that report to TransLink. The bus company is called the Coast Mountain Bus Company Ltd. (CMBC) which operates the community shuttles, conventional bus and trolleys, seabuses, and HandyDart (TransLink, Corporate Overview, 2019). Rail, the SkyTrain, is operated by the British Columbia Rapid Transit Co. Ltd. (TransLink, Corporate Overview, 2019). TransLink is part of a regional network; however, only transit networks in direct impact of zone one were analyzed within this MRP. The total operating expenses for 2018 were $\$ 1.6$ billion, and the total capital budget for 2018 was \$3.6 billion (TransLink, 2018 Year-End Financial and Performance Report, 2018).

\begin{tabular}{|c|c|c|c|c|}
\hline Statistics & SkyTrain & Buses & Seabus & $\begin{array}{c}\text { Accessible Transit } \\
\text { HandyDART }\end{array}$ \\
\hline $\begin{array}{l}\text { Vehicle } \\
\text { Types }\end{array}$ & $\begin{array}{l}\text { 1) Intermediate } \\
\text { Capacity Transit } \\
\text { System (ICTS) } \\
\text { 2)Advanced Light } \\
\text { Rapid Transit } \\
\text { (ALRT) } \\
\text { 3)Advanced Rapid } \\
\text { Transit(ART) }\end{array}$ & $\begin{array}{l}\text { 1) Compressed } \\
\text { natural gas (GNC } \\
\text { buses } \\
\text { 2)Diesel electric } \\
\text { hybrid buses } \\
\text { 3)Low emission } \\
\text { diesel buses } \\
\text { 4)Gasoline } \\
\text { powered buses, } \\
\text { diesel community } \\
\text { shuttle }\end{array}$ & $\begin{array}{l}\text { Ferries } \\
\end{array}$ & Contracted vehicles \\
\hline $\begin{array}{l}\text { Number } \\
\text { of } \\
\text { vehicles }\end{array}$ & Total.........326 & Total.....1,514 & Total...........3 & Total..........309 \\
\hline $\begin{array}{l}\text { Number } \\
\text { of } \\
\text { Riders } \\
\text { (million) }\end{array}$ & $\begin{array}{l}\text { Total.....160m } \\
\text { (2018) }\end{array}$ & Total....247Mil & Total......5.85Mil & Total......1,315 (2018) \\
\hline $\begin{array}{l}\text { Routes } \\
(\mathbf{k m})\end{array}$ & $\begin{array}{l}\text { Total.....79km } \\
53 \text { stations }\end{array}$ & $\begin{array}{l}\text { Total......... } \\
\text { Routes.....218 }\end{array}$ & $\begin{array}{l}\text { Total...... } \\
\text { Routes.......2 }\end{array}$ & \\
\hline
\end{tabular}

Source: TransLink Regional Snapshot 2017

Source: TransLink website, TransLink sees record ridership in 2017 


\subsection{Equity Policy Examination and Critique}

TransLink employs many equity policies across all areas of its transportation system, in addition, the transportation agency states that some modes are completely accessible and barrier reduction. Table 2 was created to categorize the equity and accessibility measures employed by TransLink.

\begin{tabular}{|c|c|c|c|c|c|c|}
\hline $\begin{array}{l}\text { Vancouver } \\
: \\
\text { TransLink }\end{array}$ & $\begin{array}{l}\text { Accessible mode of } \\
\text { transportation }\end{array}$ & $\begin{array}{l}\text { Equitable fare } \\
\text { structure }\end{array}$ & $\begin{array}{l}\text { Barrier } \\
\text { reduction }\end{array}$ & $\begin{array}{l}\text { Equity } \\
\text { Advisory } \\
\text { Committe } \\
\text { e }\end{array}$ & $\begin{array}{l}\text { Equity/Acce } \\
\text { ssibility } \\
\text { legislation/ } \\
\text { policies }\end{array}$ & $\begin{array}{l}\text { Equity } \\
\text { Programs }\end{array}$ \\
\hline $\begin{array}{l}\text { Vertical } \\
\text { equity } \\
\text { policies }\end{array}$ & HandyDart & $\begin{array}{l}\text { Youth fare, } \\
\text { Senior fare, } \\
\text { Post- } \\
\text { Secondary } \\
\text { fare- } \$ 41 \text { per } \\
\text { month UBC, } \\
\text { Accessible } \\
\text { transit fare, } \\
\text { CNIB } \\
\text { partnership } \\
\text { free fares, } \\
\text { BC Bus } \\
\text { Program }\end{array}$ & $\begin{array}{l}\text { Bus, } \\
\text { Skytrain, } \\
\text { Seabus, } \\
\text { all } \\
\text { accessible } \\
\text { with lift, } \\
\text { ramps. } \\
\text { All } \\
\text { SkyTrain } \\
\text { stations } \\
\text { have } \\
\text { elevators } \\
\text { Station } \\
\text { assistant } \\
\text { phone line }\end{array}$ & $\begin{array}{l}\text { HandyDart } \\
\text { User } \\
\text { Advisory } \\
\text { Committee } \\
\text { Access } \\
\text { Transit } \\
\text { User } \\
\text { Advisory } \\
\text { Committee } \\
\\
\text { Access } \\
\text { Transit } \\
\text { Team }\end{array}$ & $\begin{array}{l}\text { Bill M } 219 \\
\text { (first } \\
\text { reading) }\end{array}$ & $\begin{array}{l}\text { TravelSmart } \\
\text { (newcomers, } \\
\text { schools and } \\
\text { seniors), } \\
\text { Universal Fare } \\
\text { Gate Access } \\
\text { Program, } \\
\text { Radio } \\
\text { frequency } \\
\text { identification } \\
\text { card, } \\
\text { HandyCard } \\
\text { Program }\end{array}$ \\
\hline $\begin{array}{l}\text { Horizontal } \\
\text { equity } \\
\text { policies }\end{array}$ & & $\begin{array}{l}\text { Regular fare, } \\
\text { Monthly Pass, } \\
90 \text { Free } \\
\text { Transfer }\end{array}$ & & & & $\begin{array}{l}\text { TravelSmart } \\
\text { Business }\end{array}$ \\
\hline
\end{tabular}

HandyDart is a mode of transportation operated by TransLink, which is dedicated to providing service to persons with cognitive or physical disabilities (TransLink, HandyDart, 2019). The HandyDart service is a door-to-door service, operated through buses with its own set of eligibility requirements (TransLink, HandyDart, 2019). HandyDart buses are equipped with 
wheelchair lifts; however, there are measurement restrictions on devices that can be accommodated by the bus (TransLink, HandyDart, 2019). To access this service, riders are required to complete a form that includes a section that must be completed by a medical professional (TransLink, HandyDart, 2019). To be eligible for the service, users must meet TransLink's definition:

Eligible users are defined as persons who have either a temporary or permanent, physical or cognitive disability that is sufficiently severe that they are unable, without assistance, to use conventional transit. Applicants must be at least 12 years old. HandyDART is a door-to-door, public transit service which uses specially equipped vehicles designed to carry passengers. Visitors to the Metro Vancouver area should use the Visitor Application Form (TransLink, HandyDart \& HandyCard application form, 2013). This program discriminates against age as users must meet the minimum age of 12 years old to qualify for the service. This can be a disadvantage to youth who live with a severe cognitive or physical disability (TransLink, HandyDart \& HandyCard application form, 2013)

The service is also accessible to visitors of Metro Vancouver that complete a visitor form to access the service (TransLink, HandyDart, 2019). Persons who are socioeconomically disadvantaged and visually impaired might have trouble accessing the form without an audio feature that renders the form audible. Users would need special audio software on their computer to be able to overcome this barrier.

TransLink's fare structure employs both horizontal and vertical approaches. In keeping with the municipal scope of this MRP, only fares in Vancouver's zone one were analyzed. Examples of vertical equity fares are the U-Pass BC, a free transit partnership for Canadian National Institute for the Blind (CNIB) members, and a flat rate for HandyDart users. Litman 
(2003) explains that vertical equity are measures that are implemented to improve conditions for disadvantaged groups. TransLink brands the U-Pass as being universal because the scope of the pass is multi-modal, thereby respecting the various modes of transportation students upon which the pass can be used. The pass is valid on the Seabus, SkyTrain, and Bus (TransLink, The Universal Transit Pass, 2019). TransLink allows CNIB members to ride for free with a CNIB ID Compass Card (TransLink, CNIB ID Compass Card, 2019). CNIB users, however, do not have access to free HandyDart service (TransLink, CNIB ID Compass Card, 2019). These discounts are applied to the standard transit card, Compass Card, which both adults and youth use (TransLink, Compass Card, 2019). The Compass Card is a reloadable transit fare card that can be loaded with day passes or monthly passes (TransLink, Compass Card, 2019). There is a standard adult card and a concession card, which is for seniors 65 years and older and youth from 5-18 (TransLink, Compass Card, 2019). Another approach that TransLink employs to promote equity is a flat rate of $\$ 3$ for HandyDart users, which is a fare applied to all modes of transit (TransLink, Fare Pricing, 2019).

\begin{tabular}{l} 
Table 3: TransLink fares \\
Single ride regular fare: $\$ 3$ \\
Single ride Youth: $\$ 1.95$ (age 5-18) \\
Concession price \\
- Free for children under 5 years old \\
- Single ride Senior: $\$ 1.95$ (age $65+$ ) \\
Concession price \\
- Day pass: $\$ 10.50$ \\
- Monthly pass: $\$ 98$ \\
Equity fare: HandyDart users $\$ 3$ flat rate all modes of transit \\
Post-Secondary (e.g., UBC): $\$ 41$ \\
CNIB partnership: free Transit \\
\hline
\end{tabular}

Source: TransLink Fare Pricing, 2019 
An example of a horizontal policy applied to the fare structure is the 90-minute free transfer. This policy allows unlimited travel for the duration of 90 minutes between bus, SkyTrain and Seabus; however, it is regulated by zone, so anyone travelling outside of a zone on a pre-paid pass must first add value to their Stored Value balance (TransLink, Transferring, 2019).

In terms of barrier reduction, there are accessibility features built into TransLink's different modes of transportation (Bus, Seabus, SkyTrain). Not all of the bus stations are equipped with accessible features; however, every bus is accessible via mobility aids (TransLink, Accessible Transit, 2019). Information is available online through TransLink's Trip Planner Tool, which allows users to organize their trip and see which stations are accessible (TransLink, Accessible Transit, 2019). The Seabus stations are fully accessible as the doors at the stations were widened to allow persons using mobility devices to pass through the doors with ease (TransLink, Accessible Transit, 2019). However, there are barriers present with the ramps connecting the ferry to the terminal that change in gradation with the tide (TransLink, Accessible Transit, 2019). The extent gradation is not mentioned on the website but could affect people in wheelchairs or mobility devices, if the ramp shifts to unmanageable levels.

The SkyTrain is the most accessible of the modes of transportation employed by TransLink. All stations are accessible, and all trains have accessibility features that allow persons with physical disabilities to travel in a convenient manner (TransLink, Accessible Transit, 2019). All SkyTrain stations have elevators built into the stations (TransLink, Accessible Transit, 2019).

TravelSmart, Universal Fare Gate Access Program and the HandyCard Program are examples of the accessibility policies employed by TransLink. The Universal Fare Gate Access Program is for persons with physical impairments, so their card can be read at the fare gates 
because the program provides users with a transit card equipped with radio-frequency identification (RFID) technology that automatically opens fare gates (TransLink, Universal Fare Gate Access Program, 2019).

TravelSmart is an outreach program that provides education on transportation solutions (TransLink, TravelSmart, 2019). The program is both vertically and horizontally equitable. It is vertical in that it serves disadvantaged individuals and communities (seniors, students and newcomers), and horizontal as it serves all businesses in the community that promote and practice environmental sustainability (TransLink, TravelSmart, 2019). It is vertically equitable in how it provides transit outreach programs to disadvantaged groups such as 'newcomers,' schools, and seniors (TransLink, TravelSmart, 2019).

TransLink's outreach to newcomers focuses on new residents to the city of Vancouver (TransLink, TravelSmart, 2019). The program provides newcomers and seniors with transportation training through workshops that include information on planning, safety, and etiquette tips (TransLink, TravelSmart, 2019). The TravelSmart program also educates students on sustainable modes of transportation such as cycling and walking, while outlining benefits associated with these modes, such as how they promote health and support the environment (TransLink, TravelSmart, 2019). TransLink explains that it offers the TravelSmart training program to persons with disabilities, but does not elaborate on whether the programs are offered in an accessible format. These would include program adaptations for persons with hearing or visual impairments, whether this be through Braille or Sign Language Interpreters.

HandyCard is an example of a vertical equity approach employed by TransLink. The program allows eligible users to pay for transit at concession prices rather than standard fare prices; however, the card is not valid on HandyDart services (TransLink, HandyCard, 2019). 
Applicants apply to the card program using the same form as the HandyDart. The program's financial aims do not support persons with disabilities. The main aim of the program is to provide a financial discount to users paying concession pricing. However, TransLink states that the card only applies to conventional transportation (excluding HandyDart), yet the eligibility criteria is limited because it states eligible users must have a disability that is severe, which prohibits them from using conventional transportation (TransLink, HandyDart \& HandyCard application form, 2013). It is assumed that transit users with severe disability would be utilizing the HandyDart service, which sets its prices at a flat rate of $\$ 3$, which is $\$ 1.05$ more expensive than the concession price rates. TransLink also allows transit users who have a disability to travel with an attendant for free (TransLink, Accessible Transit, 2019). Another program that TransLink offers is an attendant program, through which a person with a disability can have a support person travel for free to aid them in their travels (TransLink, Accessible Transit, 2019). There are two advisory committees within TransLink: the Users' Advisory Committee (UAC) and the HandyDart Users' Advisory Committee (HDUAC). The UAC was established based on feedback received from the review process of the 2019 Access Transit Strategy (TransLink, Users' Advisory Committee, 2019). The UAC website is vague on details about committee membership and mandate. The website states that the UAC meets regularly throughout the calendar year, and that the mandate of the committee is promoting accessibility though creative inclusive means (TransLink, UAC, 2019). Members from the public can apply to be on the committee (TransLink, UAC, 2019). The HDUAC was formed to provide an avenue for customer and stakeholder input into the HandyDart service (TransLink, HandyDart Users' Advisory Committee, 2019). In addition, the HDUAC discusses areas of improvement with TransLink (TransLink, HDUAC, 2019). The HDUAC states that the 13-member committee is 
diverse with respect to age, persons who have a disability, and regional and municipal representation (TransLink, HDUAC, 2019).

The Spinal Cord Injury BC is a non-profit organization, the aim of which is to support persons with mobility impairments and disabilities such as spinal cord injuries. The organization provides extensive detail into the accessibility of public transportation in Vancouver and with TransLink. The organization posts on its website feedback from its stakeholders concerning the accessibility of TransLink's service. Spinal Cord Injury (2019) reports on comments received from its stakeholders (over a number of years), many of whom share the most commentary about the bus service having poor levels of accessibility service offered (Spinal Cord Injury BC, Vancouver transit accessibility, 2019). The organizations' stakeholders explain that bus drivers sometimes refuse to lower the bus ramps, and that bus stops are not truly accessible, even though they are labelled as such (Spinal Cord Injury BC, Vancouver transit accessibility, 2019). In addition, stakeholders state that the HandyDart's service is inflexible as travel bookings need to be made days in advance and so do not allow for spontaneous travel (Spinal Cord Injury BC, Vancouver transit accessibility, 2019). Another notable event reported by the non-profit organization was that, when the SkyTrain first opened, there were discussions of banning persons in wheelchairs during times of heightened transit use such as rush hour; however, this did not happen as advocates for persons with disabilities voiced strong opposition (BC Spinal Cord Injury, Accessible Transportation History, 2019). Currently, there is no legislation that mandates public or private transit companies in British Columbia to be accessible, which is why groups such as Spinal Cord Injury BC are so integral in advocating for the transportation of rights of persons with disabilities. 
Bill M 219, the British Columbia Accessibility Act, which has received only first reading in the $\mathrm{BC}$ legislature, is one response to a lack of accessibility legislation (British Columbia Legislative Assembly, Bill M 219, 2018). However, it is a Member's Bill introduced by MLA Linda Reid (Liberal: Richmond South Centre). Although Ms. Reid is the longest-serving member of the $\mathrm{BC}$ Legislature, she is currently an opposition member, so there is little guarantee that this Bill will move forward. The Bill aims to address accessibility strictly in the public sector, concerning the development of a plan to reduce barriers as well as educate society on accessibility (British Columbia Legislative Assembly, Bill M 219, 2018). The bill is legislative and regulatory, and will be enacted through regulation by the Lieutenant Governor in Council (British Columbia Legislative Assembly, Bill M 219, 2018). Accessibility Services Canada, (2018), a training organization that helps business address and adhere to accessibility standards, explains that British Columbia is the fourth province to legislate accessibility standards following Nova Scotia in 2017, Manitoba in 2013, and Ontario in 2005. The province of Ontario was one of the first to legislatively mandate transit companies to adhere to the promotion of accessibility; however, transit companies have still not fully implemented accessibility measures, but plan to have fully accessible transit systems by 2025 . The TTC's accessibility plan is outlined in Appendix A: 2019-2013 TTC Multi-Year Accessibility Plan. 


\section{Section Two: Toronto}

\subsection{Historical Analysis}

The City of Toronto's extensive transportation history dates back over 150 years. Public transportation was chartered by the City of Toronto in 1861, with a 30 -year contract for the Toronto Street Railway Company (TSRC) (Toronto Transit Commission, Milestones, 2017). Radforth (2015) explains that, by1886, the TSRC's vast transportation network in the city employed over 300 people. The TSRC employed horse-drawn streetcars (sleighs in winter), which were operated by a driver and another employee inside them who collected fares from riders (Radforth, 2015); however, the TSRC failed financially in 1869 due to low ridership Sinclair (1891).

Toronto then operated transportation services for a brief period until 1891 when a new 30-year contract was given to the Toronto Rail Company (TTC, 2017). Sinclair (1891) details that the public was dissatisfied with TSRC's management of the transit network, specifically concerning the deteriorated conditions of streetcars in the winter, especially inadequate heating systems (Sinclair, 1891). Toronto entertained the notion of assuming full control of transportation, and consulted the Ontario Government, which argued that Toronto could borrow whatever amount needed to purchase the transportation system; however, Sinclair (1891) states that Toronto was not financially ready to assume ownership of the transit system. In 1894, Toronto's transit system underwent extensive modernization with the phasing out of horse-drawn streetcars and the incorporation of electrically-powered streetcars (TTC, Milestones, 2017). Filey (1996) outlines that what is now known as the Toronto Transit Commission (TTC) was first established in 1920 after a referendum was held. Toronto residents continued to be upset with the privately-owned transportation services operating at the time, and favoured holding a referendum 
to decide this matter. Of the 23,981 people who voted in the referendum, $90 \%$ of respondents $(21,700)$ voted in favor of a municipally operated transit system for Toronto, and 2,281 voted against a municipally run transit organization (Filey, 1996).

As Toronto grew, the demands for a more extensive transit system necessitated different modes of transportation. However, these demands were not met until the mid 1940s, as from 1910 until 1946 a subway system was considered too expensive (City of Toronto, 2018). Toronto's subway system, one of the largest in Canada, dates back over a hundred years. Thousands of commuters use the underground transit network daily. Torontonians use this system to go about their daily lives. Toronto's subway system was the first in Canada (City of Toronto Archives, 2018). The plans for a subway transit system in Toronto were first conceptualized in 1910; however, they did not come to fruition until 1946 (City of Toronto Archives, 2018).

In "Reviewing and assessing the Toronto metro system," Derrible (2012) provides an extensive overview of Toronto's subway system. In the 1920s, fundamental changes were made to Toronto's transportation network, as it transitioned to public ownership and the Toronto Transit Commission was formed (Derrible, 2012).

Until the 1920s, the outer parts of Toronto were serviced by a network of lines known as the Radial Railway that extended to Lake Simcoe and Richard Hill however, in the mid-to late 1920s, radial service was replaced with motorized buses (TTC, Milestones, 2017). As Slater (1997) argues, the replacement of streetcars with buses was "simply a matter of cost" (Slater, 1997, p. 59). Buses cost significantly less to operate than streetcars because they have fewer capital cost associated with their operations. Streetcars require complex electrical wiring systems to operate them, which needs to be updated, as new electrical technology becomes available 
(Slater, 1997). Between the 1940s-1960s, there was trend in many North American cities to adopt buses over streetcars (Slater, 1997). In Toronto, buses replaced the Radial Railway.

In a 1946 referendum, Toronto residents voted to have the city invest in an underground transit system (Derrible, 2012). Toronto's first subway line opened in 1954 with twelve stations running from Union to Eglinton, servicing one of the busiest and most congested streets in Toronto: Yonge Street (Derrible, 2012). The second line (Bloor-Danforth) opened in 1966, with further extensions to both lines 1 and 2 added in the 1970s, most notably seven stations were opened on Line 1 from St. George to Wilson. In the 1980s a third metro line - the Scarborough Rapid Transit line - was established (Derrible, 2012). Finally, on November 22, 2002, Line 4 the Sheppard line - officially opened, with five stations along $5.5 \mathrm{~km}$ of track and, in 2017, Line 1 was extended to York University.

As noted above, from the 1950 s to the 1980 s, Toronto's subway system underwent many changes, due to an increasing population and the expansion of the Toronto region geographically (Derrible, 2012). Toronto's population doubled from the 1950 s to the early 2000 s to 2.5 million people (Derrible, 2012). In the 1950s the subway system had an annual ridership of 800 thousand people but, by 2008, yearly ridership was more than 200 million (Derrible, 2012).

Equitable advancements within the TTC began in the mid-20th century, with the inclusion of women as drivers and mechanics; however, this only lasted for the duration of the Second World War (TTC, Milestones, 2017). Women were not allowed to work in these capacities again until the mid-1970s. With the rise of Second Wave Feminism, the fight for women's rights occupied the fore of political discussions of equality and equitability in the 1970s, and the TTC's policies began to reflect the social changes of the era. In 1975 the TTC changed its hiring policies to include women in the workforce (TTC, Milestones, 2017). The 
policy of female inclusion in the workforce allowed women to work as operators, which had not been the case since the Second World War (TTC. Milestones, 2017), other major equitable advancements in the transit network occurred in the late 20th-century. For example, in 1996, buses began to be equipped with a lift mechanism to assist individuals with mobility assistive devices to increase accessibility to TTC services (TTC, Milestones, 2017). Three years later, accessibility on buses was further changed as buses were equipped with lower floors designed to help individuals with mobility needs (TTC, Milestones, 2017). In 2011, all TTC bus lines were made accessible throughout the city (TTC, Milestones, 2017). The features of an accessible TTC bus include designated seating reserved for persons with disabilities and seniors, automated stop announcements, and two programs that provide bus stop route accessibility: Request Stop Program and Stop between Stops (TTC, Bus Accessibility, 2017). The Request Stop Program allows customers, between the hours of 9pm to 5am, to access the "Stops Between Stops" imitative if they feel vulnerable getting off the bus at its scheduled stops (TTC, Bus Accessibility, 2017). The Stops between Stops program is similar to the aforementioned but is available any time of the day; however, if a customer is in duress, or demonstrates a "genuine need" to leave the bus, the decision to let the customer off the bus is at the discretion of the transit driver (TTC, Bus Accessibility, 2017). These two policies broaden the scope of accessibility to include a gendered lens on accessibility to potentially vulnerable transit riders.

\subsection{Overview of Transportation Structure}

The TTC provides transit to the City of Toronto and parts of the Greater Toronto Area (GTA), with the total area of coverage equating to 622 square kilometers (TTC General Information, 2019). This coverage is divided into several modes of transportation: subway, bus, and streetcars (TTC General Information, 2019). Light Rail Transit (LRT) is another mode of 
transportation operated by Metrolinx (a regional transportation organization) and the TTC, but this mode of transportation is not yet complete (TTC General Information, 2019). The modes of transpiration within the TTC's jurisdiction include the following: four subway lines (one of which, Line 3, is currently an LRT), eleven streetcar routes, and over a hundred bus routes (TTC General Information, 2019). Table 4 provides an overview of the type of vehicles, the quantity and the annual number of riders for 2017.

\begin{tabular}{|c|c|c|c|}
\hline Statistics & Subway & Buses & Streetcars \\
\hline $\begin{array}{l}\text { Vehicle } \\
\text { Types }\end{array}$ & 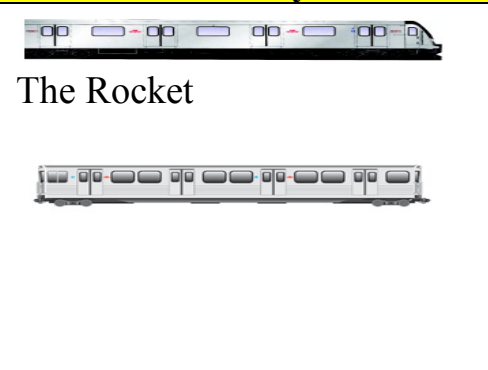 & 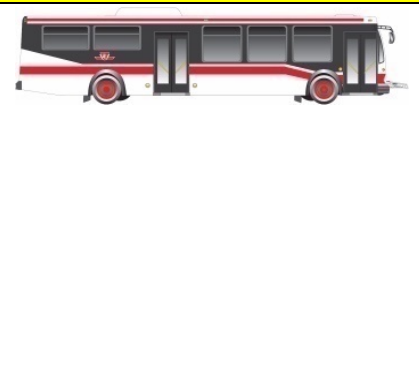 & $\begin{array}{l}\text { Pandian Light Rail Vehicle } \\
\text { Canadian } \\
\text { (CLRV) } \\
\text { Articulated Light Rail } \\
\text { Vehicle (ALRV) }\end{array}$ \\
\hline $\begin{array}{l}\text { Number } \\
\text { of } \\
\text { vehicles }\end{array}$ & $\begin{array}{l}\text { Total.......................876 } \\
\text { Subway................8. } \\
\text { Scarborough RT........28 }\end{array}$ & $\begin{array}{l}\text { Total...................1,920 } \\
12 \text { metre............1,767 } \\
18.3 \text { metre............153 }\end{array}$ & $\begin{array}{l}\text { Total.....................241 } \\
\text { CLRV ....................141 } \\
\text { ALRV .....................43 } \\
\text { 'New' low floor } \\
\text { articulated...............57 }\end{array}$ \\
\hline $\begin{array}{l}\text { Number } \\
\text { of Riders }\end{array}$ & $\begin{array}{l}\text { Total..........216,188,249 } \\
\text { Subway ......213,011,622 } \\
\text { Scarborough RT } \ldots \ldots \ldots \ldots \ldots \\
3,176,627\end{array}$ & Total........261,112,835 & Total..........55,914,914 \\
\hline $\begin{array}{l}\text { Routes } \\
(\mathbf{k m})\end{array}$ & $\begin{array}{l}\text { Total................. } 76.5 \mathrm{~km} \\
\text { (given in one-way } \\
\text { kilometres) }\end{array}$ & $\begin{array}{l}\text { Total..........6,249.8km } \\
\text { (includes roundtrip) }\end{array}$ & $\begin{array}{l}\text { Total.............344.3km } \\
\text { (includes roundtrip) }\end{array}$ \\
\hline
\end{tabular}

Source, TTC operational statistics, 2017

The governing structure of the TTC is a board, and the members include citizens of Toronto and city councillors (TTC, The Board, 2019). The current board is composed of four citizens and six Toronto City Councillors (TTC, The Board, 2019). The functions of the TTC Board include overseeing planning and policy, and expanding the service (TTC, The Board, 2019). The 2019 operating budget for the TTC is $\$ 2$ billion dollars (City of Toronto, TTC 
Budget 2019, 2019). The TTC has a capital budget of 33.5 billion dollars, which is allocated over a 15-year period (TTC, 15-Year Capital Investment Plan \& 2019-2028 Capital Budget \& Plan).

The equitability of the TTC network, in terms of the physical accessibility of the system, is detailed within the annual operating statistics. The TTC states that all modes of transportation have some level of accessibility; however, the bus system is the most accessible in terms of access for individuals with mobility impairments, compared with the streetcar and subway services. All bus routes are accessible, with the entire fleet of buses equipped with low-floor ramps (TTC General Information, 2019). These ramps allow the bus to lower or 'kneel' to help people who have mobility aids or visual impairments to more easily access the bus (TTC, Riding the Bus: Easier Access on the TTC, 2017). There is also priority seating on every bus for pregnant women, the elderly, and persons with disabilities (TTC General Information, 2019).All streetcars align with the Accessibility for Ontarians with Disability Act (AODA), in terms of providing some level of accessible seating (TTC, Riding the Streetcar, 2019). These seats are marked with signage and a blue-coloured fabric indicating that they are accessible seating (TTC, Riding the Streetcar, 2019). Each subway train is equipped with at least one car that has accessible seating (TTC, Riding the Subway, 2017). The seats can move up or down to accommodate wheelchairs and other mobility assistive technology (TTC, Riding the Subway, 2017).

A number of Toronto's streetcars are equipped with accessibility features to support people with mobility assistive devices. For example, 57 of Toronto's streetcars are equipped with low-floor ramps (TTC General Information, 2019). However, based on the number of accessibility features in the other transportation modes (bus and streetcar), the subway system is the least accessible, due to the low number of accessible features offered, both on the trains and 
in stations. Implementing accessibility features in the subway system can be a difficult endeavor due to the cost of making the structural changes to existing subway stations and the cost of building new stations that include accessible features. Out of the 75 subway stations, only 44 stations are accessible in terms of the installation of elevators, ramps and escalators, as shown in Table 5 below (TTC Schedules \& Maps, 2019).

The TTC also has a mode of transit, which is known as the Wheel-Trans Service, which is dedicated to providing accessible transit to and from bus stops and subway stations to persons with disabilities (TTC, Using Wheel-Trans, 2018). The Wheel-Trans service was started in 1975 by a private contractor who utilized vans with mechanical lifts (TTC, Milestones, 2017). The TTC assumed ownership of the Wheel-Trans Service in 1988 (TTC, Milestones, 2017). The service is currently comprised of different modes of transportation such as buses and contracted taxi minivans (TTC, Using Wheel-Trans, 2018). There are eligibility requirements to access this service, requiring applicants to answer a questionnaire and provide supporting medical documentation from a registered healthcare professional (TTC, Wheel-Trans Eligibility Application, 2019). The questionnaire is inclusive and considers many forms of disability such as mental, physical, sensory, and cognitive (TTC, Wheel-Trans Eligibility Application, 2019). Following the AODA, the service has become more inclusive and now provides more categories for eligibility. Prior to 2017, there were only two eligibility categories: temporary and permanent (TTC, Wheel-Trans Eligibility Application, 2019). Now there is a third category, 'conditional', which provides services to individuals who experience environmental or physical barriers to transit such as weather (TTC, Wheel-Trans Eligibility Application, 2019).

Table 5 depicts the level of accessibly concerning elevators and escalators installed throughout the subway network, as well as their operational status. There is also a telephone line 
that provides the operational status of elevators and escalators. This information allows users with mobility needs to plan their trips accordingly, if an elevator or escalator is down for maintenance.

\begin{tabular}{|l|l|l|l|}
\hline \multicolumn{2}{|c|}{ Table 5: Subway Accessibility Level } \\
\begin{tabular}{|l|l|l|} 
Line One: Yonge \\
University
\end{tabular} & $\begin{array}{l}\text { Line Two: Bloor- } \\
\text { Danforth }\end{array}$ & $\begin{array}{l}\text { Line Three: } \\
\text { Scarborough }\end{array}$ & Line Four: Sheppard \\
\hline $\begin{array}{l}15 \text { out of 38 Stations are } \\
\text { accessible }\end{array}$ & $\begin{array}{l}16 \text { of } 31 \text { stations are } \\
\text { accessible }\end{array}$ & $\begin{array}{l}2 \text { of } 6 \text { stations are } \\
\text { accessible }\end{array}$ & All stations are accessible \\
\hline
\end{tabular}

Source: TTC Website, 2019

\subsection{Equity Policy Examination and Critique}

The Toronto Transit Commission's focus on increasing access for transit users is documented in the TTC 1980 annual report, which references the creation of a Technical Advisory Committee on Improved Accessibility (TACIA) in 1979that aimed to improve accessibility at surface and subway facilities (TTC Annual Report, 1980). Specifically, the aim of the TACIA was to identify problematic areas in the transit line for "disabled customers" (TTC Annual Report, 1980). Once areas were identified, TACIA compiled this information and sent it to stakeholders who self-identified as "disabled customers" for their input on how to improve accessibility (TTC Annual Report, 1980). Another pivotal historical point in the 1980s was the TTC's introduction of adaptations to the transit system to support seniors and people with mobility challenges (TTC Annual Report, 1980). Currently the TTC has the Advisory Committee on Accessible Transit (ACAT), which is comprised of volunteers who are tasked with public engagement to promote accessibility within the TTC (TTC Advisory Committee on Accessible Transit, 2019). ACAT volunteers dedicate seven hours per week to discuss how accessibility services, such as the Wheel-Trans service, can better serve community needs (TTC Advisory Committee on Accessible Transit, 2019). Citizens can voice their concerns directly to the ACAT, which then reports to the Toronto Transit Commission Board (TTC Advisory Committee on Accessible Transit, 2019). 
No provincial legislation compelled public transportation agencies to create equitable public systems, until the 2005 passing of the Accessibility of Ontarians with Disabilities Act (AODA). Burns and Gordon (2010) detail that the AODA is a seminal piece of legislation and is one of the only laws in Canada that deals with promoting accessibility in all aspects. With a lack of federal legislation, Ontario is a leader in equity standards with the enactment of AODA, which provides accessibility across a wide spectrum, in particular public transportation (Burns and Gordon, 2010). The AODA sets certain standards with which transportation agencies must comply regarding people with disabilities, including accessibility training, and retrofitting transportation vehicles to make them more accessible. The AODA outlines six areas that need to be made fully accessible by 2025: Customer Service, Employment, Information and Communication, Information and Transportation, Design of Public Spaces (AODA website, 2019). The legislation provides target dates of implementation in each area (AODA, website 2019). The AODA details that transportation networks should be fully accessible by 2017. As shown in Appendix A, the TTC has not fully implemented all measures to ensure a fully accessible transit system by 2017 (AODA, website, 2019). To assure that AODA is adhered to, the law establishes reporting mechanisms and standards that the public sector and private sector must follow (Ontario Government, Accessibility laws, 2018).

To comply with the reporting mandate and goals of accessibility contained in the AODA, the TTC publishes plans and reports. The TTC outlines that its work toward ensuring accessibility within the transit system covers a wide spectrum of areas such as structural, employment, and goods and services (2019-2023 TTC Multi-Year Accessibility Plan, 2019). "Goods and services" pertain to making improvements concerning barrier reduction and improving accessibility (2019-2023 TTC Multi-Year Accessibility Plan, 2019). The TTC creates 
plans entitled "Multi-Year Accessibility Plans" that are produced every four years, and outline its goals for meeting the AODA's objectives and timelines (2019-2023 TTC Multi-Year Accessibility Plan, 2019). To track progress on these targets, the TTC posts annual reports. However, the TTC outlines, in its 2019-2023 multi-year plan, that it has been working on creating accessible services since the 1980s (2019-2023 TTC Multi-Year Accessibility Plan, 2019).

An example of a status report is the "2017 Accessibility Plan Status Report", which outlines the TTC's current strategies to make its service more accessible for persons with disabilities. Some notable reforms have been implemented at Ossington Station to make the elevator and entry access points more accessible (TTC 2017 Accessibility Plan Status Report, 2017). In addition, the TTC outlines that it is installing an audible route announcement system in buses and railcars for people with visual impairments (TTC 2017 Accessibility Plan Status Report, 2017). Along with reducing physical barriers, the TTC is also reducing economic barriers to transit accessibility. The TTC's discount for persons with disabilities is offered through "The Fair Pass Discount" program, which allows an adult resident who is on the Ontario Disability Support Service Program (ODSP), and not receiving other funding for transportation benefits, to receive a pass price at a discounted rate of $\$ 115.50$, which equates to a $\$ 30.77$ discount from the regular price (TTC, Fair Pass Discount Program, 2018). The TTC is also changing the fare structure so that, in conjunction with their employment duties of assisting person with disabilities, aides may not be required to pay a transit fare (TTC, Support for Persons Assistance Card program, 2019). Litman (2003) defines vertical equity as "subsidies to benefit a disadvantaged group such as discounted transit fares for student and elderly riders, and special mobility services for people who are physically disabled" (Litman, 2003,p. 5). The Fare Pass 
Discount program follows a vertical equity approach because it provides subsidies that are prescribed to a particular group of individuals, in this case persons with disabilities.

In "Ridership Growth Strategy," the TTC outlines equity measures to address income disparities among Toronto populations in relation to public transit. Notable measures are the "two-hour transfer fee waiver" and the "TTC-GO discounted fare" (TTC, Ridership Growth Strategy, 2018). These strategies take a horizontal approach to equity, as they apply to everyone. The "Two Hour transfer" allows any TTC rider, albeit only those with PRESTO cards, to have a time frame of two hours to go from bus, subway, or streetcar by tapping their PRESTO card (as many times) and pay one time, within the two-hour window (TTC two-hour transfer, 2018). This approach is problematic because those who have a mobility disability, like someone in a wheelchair, might take longer going from bus to subway, and will not get as much benefit from the 'two-hour transfer fee waiver' as someone who is not in a wheelchair. In addition, this does not consider traffic, or extended subway or streetcar delays. Furthermore, the Presto card is also problematic because of how it is economically structured; it requires a $\$ 10$ minimum balance, which may pose economic barriers to people from low income group (PRESTO website, loading your card, 2016).

The TTC's employs vertical and horizontal approaches to its fare structure. The Day Pass and Convention pass are examples of horizontal equity policies as they apply to everyone and are not targeted to disadvantaged groups. The Day Pass is horizontally based because its allocation is uniform to all families. For a flat rate of $\$ 13$, a family can receive unlimited travel on Saturdays and Sundays and statutory holidays (TTC website, Day Pass, 2019). The Convention Pass is horizontally based because it does not target a specific disadvantaged group and the eligibility criteria are uniform and apply to anyone holding: conventions, trade shows, meetings, and 
conferences in Toronto (TTC Convention Pass, 2019). The rates are based on the number of people and days the event is held (TTC Convention Pass, 2019). The more people and days the event can support, the cheaper is the TTC for convention attendees (TTC Convention Pass, 2019). The U-Pass is an example of a vertical equity approach because it provides students with reduced transit fees. The U-Pass is for students who are attending select post-secondary institutions full-time (TTC U-Pass, 2019). The fare structure of the U-Pass equates to $\$ 70$ per month, for a total of $\$ 280$ dollars per semester (TTC U-Pass, 2019). The cost of this pass, compared to the cost of a monthly pass, saves youth (age 13-19) \$209.80 because the current (as of July 2019) fare is currently is $\$ 122.45$ per month for a total of $\$ 489.8$ for a four-month semester (TTC Fares \& Passes, 2019). Adults attending a post-secondary institution who would pay $\$ 151.15$ for a monthly pass, would save $\$ 324.6$ if they utilize the U-Pass (TTC Fares \& Passes, 2019). However, the U-Pass has its disadvantages. The Ontario Ministry of Training Colleges and Universities outlines that compulsory fees for post-secondary institutions may include the university transit pass. Therefore, if a university votes to implement a university transit pass all students are then compelled to pay the fee for the pass (Ryerson University, Office of The Registrar, Ancillary Fee Descriptions, 2019). This decision can pose economic burdens on students as they are already burdened by the high cost of tuition and other compulsory fees, and may not need the U-Pass. Jen McMillen, Vice-Provost for Students at Ryerson University, noted that the consensus among Ryerson students, in the 2018 referendum on the RU-Pass, was that it not be adopted (McMillen, Email, 2019). 


\section{Table 6: TTC fares}

1) Regular fare: $\$ 3.25$ (adult)

2) Youth Fare: $\$ 2.20$ (age $\$ 13-19$ )

- children under 12 free

3) Senior Fare: $\$ 2.20$ (age 65+)

4)Monthly pass:

- Regular: $\$ 151.15$

- Youth: \$122.45 (age 13-19)

- Student: $\$ 122.45$

- Senior: $\$ 122.45$ (age 65+)

5) Equity offers:

- Fair Pass Discount Program

- Convention pass

- U Pass - $\$ 280$ per semester

Source: TTC website, 2019

Table Seven (pp. 37-38) depicts the equity policies analyzed in section two of this paper.

Table Seven also provides an historical overview of the various TTC equity policy initiatives, including Choices for the Future, which was implemented in the late 1980s to early 1990s, and the Accessible Transit Service Plan of 1997 (TTC, Background Legislation and Policy, 2017). These are progressive equity policies created by the TTC. The Toronto Transit Commission states it has a long-standing commitment to promoting transit equity and decreasing barriers to public transportation in Toronto, and that the aforementioned policies of the 1980 s-90s were instrumental in creating the "Easier Access" program. The aim of this program was to improve the quality of services in transit stations for individuals with accessibility needs (TTC, Background Legislation and Policy, 2017). In addition to the TTC's corporate policies, the transit organization states that it complies, or is working towards compliance, with the following policies: Accessibility for Ontarians with Disabilities Act (AODA); Accessibility Standard for Customer Service, Integrated Accessibility Standards Regulation (IASR), Ontario Building Code (OBC) and the Toronto Seniors Strategy (TTC, Background Legislation and Policy, 2017). For a 
list of all TTC equity policies and initiatives, and their compliance status with the AODA, see Appendix A document pages 55-67: “Attachment 4-AODA Integrated Accessibility Standards Regulation- TTC Compliance Status” (pg.1-13) from the 2019-2023 TTC Multi-Year Accessibility Plan.

The 2019-2013 Multi-Year Accessibility Plan outlines the different phases of projects, such as the expansion of the Fair Pass Discount Program. Phase two of the program is to extend the discount to "residents receiving child-care fee subsidies with incomes below the eligibility threshold defined as 15\% above the Low-Income Measure (LIM+15)" (2019-2023 TTC MultiYear Accessibility Plan, 2019, p. 23). Phase three is to offer the Fair Pass Discount Program to city residents who have an income below the LIM+15. (2019-2023 TTC Multi-Year Accessibility Plan, 2019). The low-income measure (LIM) is an economic indicator that accounts for household economic needs, which is based on the medium value of the income in a household (Statistics Canada, Low Income Measure, 2015). Expand Access Hubs is a policy goal of the TTC, which concerns having 10 new hubs by 2020 (2019-2023 TTC Multi-Year Accessibility Plan, 2019). Access Hubs are shelters for Wheel-Trans that allow for easier access for individuals with mobility devices and impairments (2019-2023 TTC Multi-Year Accessibility Plan, 2019).

There are financial barriers in terms of fare prices that create an inequitable subway system in Toronto. In "Next Stop Equity: Routes to fairer transit access in the Greater Toronto and Hamilton Area," Sean Hertel, Roger Keil, and Michael Collens (2016) outline the financial barriers that different groups of people experience in Toronto to access transit. The scholars' findings demonstrate that there are cost barriers for students and people of lower socioeconomic status, along with technological barriers experienced with the Presto system for those who do not 
have access to the technology (Hertel et al., 2016). The authors conducted extensive interviews with students in a literacy program in Toronto, where they asked the students if they purchased the subsidized $\$ 100$ Metropass (which regularly sells for $\$ 141.50$ ), and found that only four students confirmed that they purchased them (Hertel et al., 2016). When asked why they chose not to purchase the subsidized Metropass, some students responded stating "[it] ties up too much of my money;" "I can't afford it, even at a cheaper rate;" "it's going to school or getting food" (Hertel et al., 2016, p. 8). Moreover, the authors outline that one student stated it was more economical to purchase the TTC tokens than to buy the pass, as they only needed to use the subway certain times of the week, and that this was all they could afford (Hertel et al., 2019). Discounts that are available are based on age, and do not take other factors into consideration, such as income or economic status (Hertel et al., 2016). For example, students from wealthy families benefit from the same discounts as students from lower income families (Hertel et al., 2016). Seniors from any socio-economic background also benefit from a discounted fare as long as they are over the age of 65 and have valid ID (TTC, Senior Fare Rates, 2019).

People of low-income status also experience technological barriers accessing the PRESTO system (Hertel et al., 2016). PRESTO is an electronic payment system where an individual can pay using a card that acts like a reloadable credit card to pay for public transit like TTC and related transit services within certain regions of Ontario). Individuals can create an online account and reload their card online, through a smartphone application, or at select subway stations (PRESTO, About 2018). This system seems very convenient and accessible; however, individuals from a lower socioeconomic background might not have access to a credit card, or technology like a cellphone or the internet to fully utilize the PRESTO system (Hertelet al., 2016). Economic barriers students and individuals of a lower socioeconomic status 
experience can be solved with a vertical equitable approach (Hertel, et al., 2016). The authors utilize Litman's multi-spectrum approach to transit analysis, which links vertical equity to income and social class (Hertel et al., 2016). In "Social Inclusion as a transport planning issue in Canada," Litman (2003) argues that equitable transport is achievable, if funding, in the form of subsidies and lower prices, is provided to groups that are economically disadvantaged. However, introducing subsidies and fare decreases is a complex process, as there are many factors and stakeholders involved: budgets need to be reconfigured; different stakeholders have competing economic interests; and there also has to be studies done to see which type of subsidy will benefit the populations, and how. These studies can be costly in themselves. This is not to say that this option should not be pursued, only that it will take careful planning and implementation.

A lack of close proximity to subway stations for lower-income communities is another issue that is still prevalent within the City of Toronto. In CityMetric, Sanjana Varghese (2018) reports that people from lower socioeconomic backgrounds, and some immigrant populations, in Toronto experience longer commuting times to access the subway. There is a lack of subway coverage beyond Toronto's downtown core (Varghese, 2018). In terms of proximity, subway coverage is still lacking in Toronto, particularly in the "underserved inner suburbs" that have high populations of low-wage workers and immigrants (Varghese, 2018). He explains that these areas are known as 'Neighborhood Improvement Areas' (Varghese, 2018). Varghese's arguments are supported by data analysed by David Hulchanski. In "Three Cities Within Toronto: Income Polarization Among Toronto's Neighbourhoods 1970-2005,” Hulchanski (2006) divides city dwellers into three categories: City 1, high-income earners; City 2, middleincome earners; and City 3, low-income earners. He provides data on a number of social indicators: income per household, mobility, crime and safety, commuting times, etc. 
(Hulchanski, 2006). There are a higher number of City 3 residents who have to spend more time traveling to access a subway than City 1 residents (Hulchanski, 2006). The data in the study depict a higher number of subway stations in City 1 areas (40 stations), while in City 3 there are 19. (Hulchanski, 2006).

Persons with mobility impairments may have trouble accessing the TTC subway services, due to the lack of infrastructure to assist with accessing the underground transportation network. Infrastructure barriers include steep flights of stairs, and a lack of wheelchair ramps and elevators. Anjana Aery (2016) from the Wellesley Institute demonstrates that persons in wheelchairs still experience infrastructural barriers to using the Toronto subway system. Only 34 subway stations out of the 69 in Toronto have an elevator, despite the fact that Canada has ratified the United Nations Convention on the Rights of Persons with Disabilities (CRPD) (Aery, 2016). The treaty came into effect on May 3, 2008 with the aim to:

...promote, protect and ensure the full and equal enjoyment of all human rights and fundamental freedoms by all persons with disabilities, and to promote respect for their inherent dignity. Persons with disabilities include those who have longterm physical, mental, intellectual or sensory impairments which in interaction with various barriers may hinder their full and effective participation in society on an equal basis with others. (United Nations, Convention on the Rights of Person with Disabilities and Option Protocol, p. 4)

Recently, the federal government and the City of Toronto began working on providing more accessibility in the Toronto subway system (Aery, 2016). The federal government allocated \$500- million to the TTC for infrastructure spending (Aery, 2016). 


\subsubsection{Equity Policy Cross-Examination: Toronto and Vancouver}

TransLink and the TTC are similar in that they both offer modes of transportation that are dedicated to providing transit to persons with disabilities, fare structures that offer discounts to students and seniors, and both systems have committees to advise on accessibility matters. However, the TTC does not offer a more equitable transportation network than that of TransLink. TransLink's vertical and horizontal equity policies support a wider number of users than the equity policies employed by the TTC. TransLink's vertical equity policies are more comprehensive in relation to the following: equitable fare structures, barrier reductions, its Equity Advisory Committee, and other equity programs offered (see table 7). Unlike the TTC, TransLink has modes of transportation, like the SkyTrain, which are entirely accessible. The TTC is still in the process of upgrading its network. In its 2019-2023 Multi-Year Accessibility Plan, the TTC claims that 21 subway stations will be retrofitted with elevators along with 52 other accessibility initiatives to make the network more accessible. 


\begin{tabular}{|c|c|c|c|c|c|c|}
\hline $\begin{array}{l}\text { Vancouver: } \\
\text { TransLink }\end{array}$ & $\begin{array}{l}\text { Accessible } \\
\text { mode of } \\
\text { transportation }\end{array}$ & $\begin{array}{l}\text { Equitable } \\
\text { fare structure }\end{array}$ & $\begin{array}{l}\text { Barrier } \\
\text { reduction }\end{array}$ & $\begin{array}{l}\text { Equity } \\
\text { Advisory } \\
\text { Committee }\end{array}$ & $\begin{array}{l}\text { Equity/Accessibility } \\
\text { legislation/ policies }\end{array}$ & $\begin{array}{l}\text { Equity } \\
\text { Programs }\end{array}$ \\
\hline $\begin{array}{l}\text { Vertical } \\
\text { equity } \\
\text { policies }\end{array}$ & HandyDart & $\begin{array}{l}\text { Youth fare } \\
\text { Senior fare } \\
\text { Post- } \\
\text { Secondary } \\
\text { fare- \$41 per } \\
\text { month UBC } \\
\text { Accessible } \\
\text { transit fare } \\
\text { CNIB } \\
\text { partnership } \\
\text { free fares } \\
\text { BC Bus } \\
\text { Program }\end{array}$ & $\begin{array}{l}\text { Bus, } \\
\text { Skytrain, } \\
\text { Seabus, } \\
\text { West } \\
\text { Coast } \\
\text { Express - } \\
\text { all } \\
\text { accessible } \\
\text { with lift, } \\
\text { ramps. } \\
\text { All } \\
\text { SkyTrain } \\
\text { stations } \\
\text { have } \\
\text { elevators } \\
\text { Station } \\
\text { assistant } \\
\text { phone } \\
\text { line }\end{array}$ & $\begin{array}{l}\text { HandyDart } \\
\text { User } \\
\text { Advisory } \\
\text { Committee } \\
\text { Access } \\
\text { Transit } \\
\text { User } \\
\text { Advisory } \\
\text { Committee } \\
\text { Access } \\
\text { Transit } \\
\text { Team }\end{array}$ & $\begin{array}{l}\text { Bill M } 219 \text { (first } \\
\text { reading) }\end{array}$ & $\begin{array}{l}\text { TravelSmart } \\
\text { Universal Fare Gate } \\
\text { Access Program } \\
\text { Radio frequency } \\
\text { identification card } \\
\text { HandyCard } \\
\text { Program }\end{array}$ \\
\hline $\begin{array}{l}\text { Horizontal } \\
\text { equity } \\
\text { policies }\end{array}$ & & $\begin{array}{l}\text { Regular fare } \\
\text { Off-Peak } \\
\text { cheaper fare } \\
\text { Monthly Pass }\end{array}$ & & & & \\
\hline $\begin{array}{l}\text { Toronto: } \\
\text { TTC }\end{array}$ & $\begin{array}{l}\text { Accessible } \\
\text { mode of } \\
\text { transportation }\end{array}$ & $\begin{array}{l}\text { Equitable } \\
\text { fare structure }\end{array}$ & $\begin{array}{l}\text { Barrier } \\
\text { Reduction }\end{array}$ & $\begin{array}{l}\text { Equity } \\
\text { Advisory } \\
\text { Committee }\end{array}$ & $\begin{array}{l}\text { Equity/ } \\
\text { Accessibility } \\
\text { legislation/policies }\end{array}$ & $\begin{array}{l}\text { Equity } \\
\text { Programs }\end{array}$ \\
\hline $\begin{array}{l}\text { Vertical } \\
\text { Equity } \\
\text { Policies }\end{array}$ & Wheel-Trans & $\begin{array}{l}\text { 1) Student } \\
\text { fare } \\
\text { 2) Seniors } \\
\text { fares } \\
\text { 3) U-pass } \\
\text { 4) Fare Pass } \\
\text { Discount } \\
\text { 5) CNIB } \\
\text { discount }\end{array}$ & $\begin{array}{l}\text { 1) } \\
\text { Audible } \\
\text { Routes } \\
\text { 2) } \\
\text { Elevators } \\
\text { 3) Lifts } \\
\text { for buses }\end{array}$ & $\begin{array}{l}\text { Advisory } \\
\text { Committee } \\
\text { on } \\
\text { Accessible } \\
\text { Transit } \\
\text { (ACAT) }\end{array}$ & $\begin{array}{l}\text { Legislation: } \\
\text { AODA } \\
\text { Policies: } \\
\text { 1)Choices for the } \\
\text { Future (1989) } \\
\text { 2) Accessible } \\
\text { Transit Services } \\
\text { Plan (1997) } \\
\text { 3) Easier Access } \\
\text { Program } \\
\text { 4) Toronto Seniors } \\
\text { Strategy } 2013\end{array}$ & $\begin{array}{l}\text { Diversity and } \\
\text { Inclusion Lens and } \\
\text { Toolkit }\end{array}$ \\
\hline
\end{tabular}




\begin{tabular}{|l|l|l|l|l|l|l|}
\hline & & & & & $\begin{array}{l}\text { 5) TTC Corporate } \\
\text { Policy }\end{array}$ & \\
\hline $\begin{array}{l}\text { Horizontal } \\
\text { equity } \\
\text { policies }\end{array}$ & $\begin{array}{l}\text { 1)Convention } \\
\text { pass } \\
\text { 2) Two-Hour } \\
\text { Transfer Fee } \\
\text { waiver }\end{array}$ & & & & & \\
\hline
\end{tabular}

This section will compare the City of Vancouver's TransLink fare structure with that of the TTC. Other fares employed by TransLink relate to its regional service and are therefore beyond the scope of this MRP. Both transit networks employ the same level of equity in regard to fare structure. For example, they both target disadvantaged groups as exemplified with the Fare Discount Program by the TTC and the HandyDart Fare program employed by TransLink. However, TransLink's fare structure is more economical, as is its pass for post-secondary students and its single fares are considerably cheaper than those offered by the TTC. Outlined in the fare comparison table is a comparative overview of the entire fare structure across both systems. 


\section{Table 8: Fare Comparison: TTC versus TransLink}

\begin{tabular}{|c|c|}
\hline TTC fares & TransLink fares \\
\hline Single ride regular fare: $\$ 3.25$ & Single ride regular fare: $\$ 3$ \\
\hline Single ride Youth: $\$ 2.20$ (age 13-19) & Single ride Youth $\$ 1.95$ (age 5-18)Free for \\
\hline Free for children under 12 years old & children under 5 years old \\
\hline Single ride Senior: $\$ 2.20$ (age $65+$ ) & Single ride Senior: $\$ 1.95$ (age $65+$ ) \\
\hline Monthly pass: & Day pass: $\$ 10.50$ \\
\hline - Regular: $\$ 151.15$ & Monthly pass: $\$ 98$ \\
\hline - Youth: $\$ 122.45$ & Post-Secondary (e.g., UBC \$41) \\
\hline - $\quad$ Student: $\$ 122.45$ & Equity fare: \\
\hline - Senior: $\$ 122.45$ & HandyDart users \$3 flat rate \\
\hline $\begin{array}{l}\text { Convention Pass: (rates based on group } \\
\text { size and length) }\end{array}$ & (all modes of transit) \\
\hline Equity fare: Fair Discount Program (FDP) & \\
\hline - Single fare $\$ 2.05$ & \\
\hline - $\quad$ Monthly pass $\$ 119.40$ & \\
\hline
\end{tabular}

Source: TTC website; fares

Source: TransLink website; fares

Both networks employ a discount to select disadvantaged groups. However, TransLink offers more economical discounts to select groups and covers a wider array of disadvantaged groups through its programs than do the TTC's equity programs. The HandyDart program, when compared to the Fair Discount Program (FDP), has a more expensive single fare of \$3; however, its monthly pass is less expensive than the TTC's FDP which costs $\$ 119.40$ (City of Toronto, Fair Discount Program, 2019) The TTC's FDP only covers one disadvantaged group: persons with disabilities, while TransLink offers the BC bus program for two groups: persons with disabilities and seniors. Of the latter, it refers specifically to seniors who are 60 years old and receiving disability assistance, or income assistance, or living on First Nations reserve, or other criteria as indicated on its website (Government of British Columbia, B.C Bus Pass, 2019). In terms of committees within the transit organizations that promote equity, TransLink employs a more comprehensive committee structure with three committees who assist in an advisory role to 
promote inclusivity for persons with accessibility issues. In comparison, the TTC only has one: the Advisory Committee on Accessible Transit.

A notable difference between the two transit systems is legislation that enforces accessibility standards on public transportation agencies. In British Columbia, there is currently no legislation that mandates public transportation operators to provide accessible transportation. Nonetheless, the B.C. government is considering such legislation. The British Columbia Accessibility Act (Bill M 219) was introduced by Liberal MLA Linda Reid and has received first reading in the B.C Legislative Assembly. In Ontario, there is comprehensive legislation, the AODA that enforces accessibility standards on both the private sector and public sector transportation agencies. However, TransLink has employed many equity policies without the enforcement of legislation. 


\section{Section Three: Montréal}

\subsection{Historical Analysis}

Montréal is one of Canada's oldest cities and its transportation network is comprised of the following: bus, subway, and tramway. Each mode of transportation was developed at different historical periods. The first mode of transportation in the city was the tramway, which dates back to 1861 , followed by the introduction of a bus system in 1919 , and the completion of the subway network in 1966 (Tramways History, 2019, Bus History, 2019; 50 Years of Métro History, 2019). Beginning in 1936, the bus system gradually replaced the tramway (STM, Bus History, 2019).

Tramways were established by the Montréal City Passenger Railway Company (MCPRC) in 1861, and were operated by a horse pulling a tram (carriage with seats) (STM Tramway History, 2019). The Montréal Street Railway Company (MSRC) took over the MCPRC in 1886 and replaced the horses with electric tramways in 1892 (Tramway History, 2019). Veilleux (1996) explains that the MSRC had a monopoly over the tramway network in Montreal due to the MSRC's prior acquisitions of other tramway companies, such as the Montreal Park and Island Railway Company and the Montreal Terminal Railway Company. In 1910, a wealthy businessman, A. E. Robert, took control over the MSRC, and a year later he merged the two companies into one to create the Montréal Tramways Company (MTC) (Veilleux, 1996). There were many complications with the tramway system (Veilleux, 1996). For example, the tramway network was designed to converge all lines into a central point, thus causing immense congestion (Veilleux, 1996). In addition, the tram cars over-crowded the streets and the trams were infrequent in their stops to pick up people (Veilleux, 1996). 
In 1912, the Montréal Tramways Company perceived a threat when the Canadian Autobus Company proposed the introduction of a bus line in the city (Veilleux, 1996). The notion put forward by the CAC created a huge dispute within the MTC, who felt that its transportation monopoly would be diminished (Veilleux, 1996). The proposal came at the same time MTC was trying to extend its contract with the City of Montréal. (Veilleux, 1996). MTC engaged with the City and CAC in legal battles that went on for a year, until 1913, when MTC bought out CAC and introduced its own bus line (Veilleux, 1996). Dale Gilbert and Claire Poitras (2015) explain that during the 1930s, the MTC grossly mismanaged its transit operations, which resulted in immense public dissatisfaction and mass congestions in the lines. To solve the congestion problem, the MTC employed vehicles that had previously been taken out of commission due to their poor condition (Gilbert and Poitras, 2015).

During the Second World War, rationing was implemented on resources such as gasoline, which led to an increase of people utilizing public transit, and this resulted in overcrowding reaching critical levels on the transit system (Gilbert and Poitras, 2015). The City asked MTC to commission a report on the feasibility of developing and installing a subway (Gilbert and Poitras, 2015). The report done by MTC favored a subway system; however, the city was apprehensive of the company taking on this project due to its mismanagement of the current transportation system (Gilbert and Poitras, 2015). In 1948, the Province of Québec became involved in a dispute between the MTC and the City of Montreal, after the City refused to let the company impose a fare increase (Gilbert and Poitras, 2015). The Québec Government set up an arbitration committee to study the situation regarding the services and type of operations the MTC was conducting (Gilbert and Poitras, 2015). In 1949, the committee issued a report that recommended that all public transportation matters fall under the jurisdiction of the municipality (Gilbert and 
Poitras, 2015). Thus, in 1951, the Montréal Transportation Commission was established (Gilbert and Poitras, 2015).

Accessibility advancements with transportation in Montréal occurred after the Second World War (STM, paratransit history, 2019). The STM correlates its paratransit service with that of the Montreal Tramway Company, which converted a bus by adding a ramp to help injured veterans utilize transportation (STM, paratransit history, 2019). The current paratransit service is a vehicle that is retrofitted to allow for easier access for persons with disabilities (STM, what is paratransit, 2019). The full adoption of this service did not occur until the 1970s, when two brothers, Jacques and Jean-Marc Forest retrofitted a vehicle to allow them to access it with their wheelchairs. They then started a company called Minibus Forest to provide services to persons with disabilities (STM, paratransit history, 2019). In the late 1970s, the company had 16 retrofitted vehicles in operation. In Québec, offering vehicles with adaptations for persons with disabilities did not become publicly mandatory until 1980 when the provincial government made it mandatory for public transit companies to provide services to persons with disabilities (STM, paratransit History, 2019). Advancements in the paratransit services occurred throughout the late $20^{\text {th }}$-century, from the installation of hydraulic lifts in all buses, to a computerised booking system that was introduced due to nearly 200,000 paratransit trips occurring in 1991 (STM, paratransit history, 2019).

\subsection{Overview of Transportation Structure}

The STM operates various modes of transportation that include subway, bus, paratransit and taxi services. Table Nine, below, provides the operational statistics of the STM concerning the modes of transportation, number of vehicles per mode, ridership and route quantities. The corporate structure of the STM is based on a Board of Directors (STM, Board of Directors, 
2019). The Board of Directors approves the annual budget, which includes operational and capital expenditures as well as employee levels (STM, Board of Directors, 2019). The Board also approves the operational strategic plans for the network. The composition of the STM Board is divided between five city councillors and five public transit users (STM, Board of Directors, 2019). Board members operate in three different capacities: work sessions, public, and committee meetings. There are ten public meetings held throughout the year, where attendees may debate the STM agenda, while work sessions are held to conclude what was discussed at public meetings. Within the Board are five different committees, service and accessibility, finance, asset management, ethics, and human resources. The committee tasked with accessibility is called the "Customer Service and Universal Accessibility Committee" (CSUAC) (STM, Customer Service and Universal Accessibility Committee, 2019). The CSUAC makes recommendations to the STM Board in three different areas; service to STM passengers, relations between ethnocultural communities and visible minorities, and creating universal accessibility (STM, Customer Service and Universal Accessibility Committee, 2019). The total operating budget for the STM for 2019 is $\$ 1.460$ billion dollars, the operating expenses are \$1.310 billion and the capital expenses are \$149 million dollars (STM 2019 Budget, 2019). 


\begin{tabular}{|c|c|c|c|}
\hline & Subway & Bus & Paratransit \\
\hline $\begin{array}{l}\text { Number } \\
\text { of } \\
\text { vehicles }\end{array}$ & $\begin{array}{l}\text { Total...................846 } \\
\text { AZUR...................423 } \\
\text { MR-73................423 } \\
47 \text { trains }\end{array}$ & $\begin{array}{l}\text { Total..............1,808 } \\
12 \mathrm{~m} \ldots \ldots \ldots \ldots \ldots \ldots 1,551 \\
18 \mathrm{~m} \ldots \ldots \ldots \ldots \ldots \ldots . . \ldots \ldots \ldots \\
\quad \text { Minibus................ }\end{array}$ & $\begin{array}{l}\text { Total...............1,586 } \\
\text { Minibus...............86 } \\
\text { Taxi................ } 1,500\end{array}$ \\
\hline $\begin{array}{l}\text { Number } \\
\text { of Riders }\end{array}$ & $\begin{array}{l}\text { Total..............271.4m } \\
(2018)^{\wedge}\end{array}$ & Total..............3,82m & $\begin{array}{l}\text { Total................32,000 } \\
\text { (active clients) }\end{array}$ \\
\hline $\begin{array}{l}\text { Routes } \\
(\mathbf{k m})\end{array}$ & $\begin{array}{l}\text { Total..................71km } \\
68 \text { stations } \\
\text { (given in one-way } \\
\text { kilometres) }\end{array}$ & $\begin{array}{l}\text { Total..........360.4km } \\
\text { (includes roundtrip) } \\
\text { Lines..............222 }\end{array}$ & Number of trips...4.4km \\
\hline
\end{tabular}

Sources: 2018 and 2019 Annual Budgets

\subsection{Equity Policy Examination and Critique}

The Société de transport de Montreal's (STM) equitability policies and measures focus on the issue of accessibility to reduce barriers for persons with mobility or visual impairments (STM, using public transit in a wheelchair, 2019). The subway system, as well as the bus network, are accessible to users with mobility equipment (STM, using public transit in a wheelchair, 2019). The different types of accessibility features for bus and subway are outlined on the STM website (STM, Accessibility, 2019). There are elevators for use in the subway stations; however, not all of the subway lines have this feature (STM, using public transit in a wheelchair, 2019). The Green and Orange STM lines are the most wheelchair accessible:

fourteen stations between the two lines have elevators (STM, using public transit in a wheelchair, 2019). There is also an option to have an STM employee assist persons with mobility challenges with travel from station to station (STM, using public transit in a wheelchair, 2019). This 
assistance provides riders with help entering and exiting the subway-car, and with utilizing the elevators (STM, using public transit in a wheelchair, 2019). Most of the bus network is wheelchair accessible; however, some of the minibus routes, such as the Navette or 212 bus to Saint-Anne, do not have wheelchair accessibility features (STM, using public transit in a wheelchair, 2019). The bus accessibility feature is a ramp that allows a wheelchair to roll onto the bus (STM, using public transit in a wheelchair, 2019).

The STM helps individuals who have an intellectual or visual disability by allowing their accompanying aides to ride public transit free of charge (STM, Accessibility for the visually or intellectual disabled, 2019). An aide can obtain entry to the transportation system free of charge by using a Companion Card, which must be presented to the transit driver (STM, Accessibility for the visually or intellectual disabled, 2019). Contained in Strategic Plan 2020 are the STM's priorities for the year. This plan's equitably policies have to do with horizontal equity in the form of barrier reductions.

The STM has a "door-to-door" service called Paratransit (STM, What is paratransit? 2019). To be eligible for this service, there are criteria the STM outlines (STM, what is paratransit, 2019). To access the service, STM states that eligible members must qualify as a "handicapped person, that is, a person with a deficiency causing a significant and persistent disability, who is liable to encounter barriers in performing everyday activities" (STM, What is paratransit? 2019). The language in this translated definition is neither current nor sensitive. Jaun Bornman (2004) argues that the terminology of 'handicap' is problematic because it classifies individuals based on circumstances and not based on a person's attributes. The term 'healthcondition' is a more appropriate term than disabled person, as the latter defines the individual, and the former equates it as an aspect of the person. The Quebec government acknowledges a 
more socially-acceptable term as 'disability', and so does the STM. The Office des Personnes Handicapées is a governmental agency tasked with advising the government on promoting inclusivity and advocating for persons with disabilities (Office des Personnes Handicapées, Publication, 2019). The Agency, in one of its regular cyber bulletins, outlines the correct societal term to be used in addressing a person with a health condition:

Important to consider. It is not always necessary to name a person's disability. After all, it is only one of their characteristics. A person is also female or male, who has long or short hair, is of one ethnic origin or another, etc. We should specify the disability or infirmity only if we wish to speak of it specifically, and not as a way of qualifying a person.

(Personal translation from Personnes Handicapées, Better Understand in 3 Minutes) ${ }^{1}$. The Agency is saying that emphasis should be placed on the person not the disability. The person is also a man or woman, and with different physical and ethnic characteristics, and that disability should not be used to qualify a person (Office des Personnes Handicapées, Better Understand in 3 Minutes, 2019). The STM utilizes the term 'disabled' in the context of describing a person on the French version of its paratransit website: 'les personnes handicapées' (person with disabilities) (STM, paratransit eligibility criteria, 2019).

A 2018 diversity survey conducted by STM illustrates that there are more Caucasian, middle aged men who do not have a disability working for STM than any other group of people (STM website, Diversity, 2019). Men make up 76\% of the STM workforce compared to 23.6\%

\footnotetext{
${ }^{1}$ The original quotation appears in French:

À bien y penser. Il n'est pas toujours nécessaire de nommer l'incapacité d'une personne. Après tout, ce n'est qu'une de ses caractéristiques. La personne est aussi une femme ou un homme, qui porte les cheveux longs ou courts, d'une origine ethnique ou d'une autre, etc. On ne devrait spécifier la déficience ou l'incapacité que si l'on veut en parler spécifiquement et non pour qualifier une personne (Office des Personnes Handicapées, Better Understand in 3 Minutes, 2019). Some anglophone Quebeckers may find the agency's use of French inaccessible or offensive.
} 
of women (STM website, Diversity, 2019). Minorities only make up 31\% of the workforce compared to $68 \%$ Caucasian (STM website, Diversity, 2019 ). The STM has a diversity policy that dates back over 30 years; however, statistics on representation from STM depict employment within STM is not equal regarding gender and ethnicity (STM website, Diversity, 2019).

Concerning the two theoretical lenses of vertical and horizontal equity, in relation to the STM, Sean Hertel, Roger Keil, Michael Collens (2016) note vertical equity to fare structures, and transit affordability measures. There are vertical equity policies employed by STM, in terms of a structured fare system for seniors 65 years old (and above) and students aged 6-17 for the bus and subway systems (STM, Fares, 2019). For these two groups, the fares are reduced by $40 \%$ with an OPUS card (STM, Transit Fares, 2019). An OPUS card is a reloadable electronic transaction card to which STM transit fare ticket purchases are applied (STM, OPUS card, 2019). Post-secondary students have access to reduced fares if they attend an educational institution approved by the Ministry of Education and Higher Teaching (STM, reduced fare students, 2019).

The STM includes a number of horizontal equity policy within its fare structure. There is the: Group Transfer, Unlimited Weekend, Unlimited Evening, Weekly Pass, 2 trips, and 10 trips fare. The Group Fare is a flat fare rate for "group composed of one adult and a maximum of ten children aged 6-13" (STM, Group Fares, 2019). For Todd Litman (2003), horizontal equity is the equal and fair allocation of resources to a group of individuals, so the different fares that STM employs exemplify this type of equity as they broadly apply. Moreover, the Unlimited Weekend, Evening, and Weekly Passes are associated with flat rates and have time restrictions on when they can be utilized, but anyone is eligible to purchase them. There is no specific age, gender, or 
disability qualification for these passes. The 2-trip and 10-trip fares are horizontally based and apply to anyone. The Group Transfer is horizontally based because it applies to any group of one adult and up to ten children within the age group of 6-13 (STM, Group Transfer, 2019).

\subsubsection{Equity Policy Cross-Examination: Montréal and Vancouver}

The STM does not employ a more equitable transportation network than that of TransLink. TransLink's vertical and horizontal equity policies support a wider number of users than the equity policies employed by the STM. Much like the case with the TTC, TransLink's vertical equity policies are more comprehensive than STM's, and are based on the same categories: equitable fare structures, barrier reductions, an Equity Advisory Committee, and other equity programs offered (See Table 10). Unlike STM, the entire TransLink network has some form of barrier reduction in place, with the SkyTrain network having accessibility features built into its system, whereas, only 14 of the STM stations have implemented accessibility features such as elevators. Table 10 applies the same TransLink zone fare restrictions as Table 7 did with Toronto. Once again only the metro Vancouver (zone 1) fare structure was analysed against that of the STM.

\begin{tabular}{|c|c|c|c|c|c|c|}
\hline $\begin{array}{l}\text { Vancouver: } \\
\text { TransLink }\end{array}$ & $\begin{array}{l}\text { Accessible } \\
\text { mode of } \\
\text { transportation }\end{array}$ & $\begin{array}{l}\text { Equitable } \\
\text { fare } \\
\text { structure }\end{array}$ & $\begin{array}{l}\text { Barrier } \\
\text { reduction }\end{array}$ & $\begin{array}{l}\text { Equity } \\
\text { Advisory } \\
\text { Committee }\end{array}$ & $\begin{array}{l}\text { Equity/Accessibility } \\
\text { legislation/ policies }\end{array}$ & $\begin{array}{l}\text { Equity } \\
\text { Programs }\end{array}$ \\
\hline $\begin{array}{l}\text { Vertical } \\
\text { equity } \\
\text { policies }\end{array}$ & HandyDart & $\begin{array}{l}\text { Youth fare } \\
\text { Senior fare } \\
\text { Post- } \\
\text { Secondary } \\
\text { fare- } \$ 41 \\
\text { per month } \\
\text { UBC } \\
\text { Accessible } \\
\text { transit fare } \\
\text { CNIB } \\
\text { partnership } \\
\text { free fares }\end{array}$ & $\begin{array}{l}\text { Bus, } \\
\text { Skytrain, } \\
\text { Seabus, } \\
\text { West Coast } \\
\text { Express all } \\
\text { accessible } \\
\text { with lift, } \\
\text { ramps } \\
\text { All } \\
\text { SkyTrain } \\
\text { stations } \\
\text { have } \\
\text { elevators } \\
\text { Station }\end{array}$ & $\begin{array}{l}\text { HandyDart } \\
\text { User } \\
\text { Advisory } \\
\text { Committee } \\
\text { Access } \\
\text { Transit User } \\
\text { Advisory } \\
\text { Committee } \\
\text { Access } \\
\text { Transit Team }\end{array}$ & & $\begin{array}{l}\text { TravelSmart } \\
\text { Universal } \\
\text { Fare Gate } \\
\text { Access } \\
\text { Program } \\
\text { Radio } \\
\text { frequency } \\
\text { identification } \\
\text { card } \\
\text { HandyCard } \\
\text { Program }\end{array}$ \\
\hline
\end{tabular}




\begin{tabular}{|c|c|c|c|c|c|c|}
\hline & & & $\begin{array}{l}\text { assistant } \\
\text { phone line }\end{array}$ & & & \\
\hline $\begin{array}{l}\text { Horizontal } \\
\text { equity } \\
\text { policies }\end{array}$ & & $\begin{array}{l}\text { Regular } \\
\text { fare } \\
\text { Off-Peak } \\
\text { cheaper } \\
\text { fare } \\
\text { Monthly } \\
\text { Pass }\end{array}$ & & & & \\
\hline \multicolumn{7}{|c|}{ Equity Policy Comparison table: STM versus TransLink } \\
\hline $\begin{array}{l}\text { Montreal: } \\
\text { STM }\end{array}$ & $\begin{array}{l}\text { Accessible } \\
\text { mode of } \\
\text { transportation }\end{array}$ & $\begin{array}{l}\text { Equitable } \\
\text { fare } \\
\text { structure }\end{array}$ & $\begin{array}{l}\text { Barrier } \\
\text { Reduction }\end{array}$ & $\begin{array}{l}\text { Equity } \\
\text { Advisory } \\
\text { Committee }\end{array}$ & $\begin{array}{l}\text { Equity/ Accessibility } \\
\text { legislation/ policies }\end{array}$ & $\begin{array}{l}\text { Equity } \\
\text { Programs }\end{array}$ \\
\hline $\begin{array}{l}\text { Vertical } \\
\text { Equity } \\
\text { Policies }\end{array}$ & $\begin{array}{l}\text { Paratransit } \\
\text { Service }\end{array}$ & $\begin{array}{l}\text { Post- } \\
\text { Secondary } \\
\text { fare } \\
\text { Senior fare }\end{array}$ & $\begin{array}{l}14 \text { subway } \\
\text { stations } \\
\text { with } \\
\text { elevators }\end{array}$ & $\begin{array}{l}\text { Customer } \\
\text { Service and } \\
\text { Universal } \\
\text { accessibility } \\
\text { committee } \\
\text { (CSUAC) }\end{array}$ & $\begin{array}{l}\text { Act to Secure } \\
\text { Handicapped Persons } \\
\text { in the Exercise of their } \\
\text { Rights (ASHPER) }\end{array}$ & $\begin{array}{l}\text { Companion } \\
\text { card }\end{array}$ \\
\hline $\begin{array}{l}\text { Horizontal } \\
\text { equity } \\
\text { policies }\end{array}$ & & $\begin{array}{l}\text { Regular } \\
\text { fare } \\
\text { Group fare } \\
\text { Unlimited } \\
\text { Pass } \\
\text { Weekend } \\
\text { Pass }\end{array}$ & & & & \\
\hline
\end{tabular}

TransLink has more vertical equity policies in its fare structure than STM, which offers only a couple of programs (HandyDart, BC Bus Program) dedicated to aiding disadvantaged groups.

STM does not have comparable programs. The fare structure employed by STM is more economical when comparing to the single regular fare rates of TransLink. In addition, STM employs more horizontal-based fares and its monthly passes are cheaper than the price of TransLink's monthly pass. However, the STM does not have a monthly pass dedicated to a disadvantaged group such as TransLink's HandyDart monthly pass, which offers a discounted rate to persons with disabilities. 


\begin{tabular}{|l|l|}
\hline \multicolumn{2}{|c|}{ Table 11: Fare Comparison: STM versus TransLink } \\
\hline \multicolumn{1}{|c|}{ Montreal STM fares } & \multicolumn{1}{|c|}{ Vancouver TransLink fares } \\
\hline Single ride regular fare: \$3.50 & Single ride regular fare: \$3 \\
Single ride Youth fare: \$2.5 (ages 6-17) & Single ride Youth\$1.95 \\
Free for children under 6 years old & Free for children under 5 years old \\
Senior Fare: \$2.5 (Ages 65+) & Single ride Senior: \$1.95 \\
Day Pass: \$10 & Day pass: \$10.50 \\
Unlimited Weekend Pass: \$14 & Monthly pass: \$98 \\
Unlimited Evening Pass & Equity fare: HandyDart users \$ flat rate \\
Monthly Pass: \$86.5 & all modes of transit \\
Monthly Youth \$52 & \\
Monthly Senior \$52 & \\
Equity fare: none & \\
\hline
\end{tabular}

Source: STM website, TransLink Website, 2019

The Committee structure TranLink has implemented with regard to advisory and advancement on equity matters is more extensive than that of STM, with TransLink employing three committees as opposed to STM's one committee. Lastly, there are more equity programs employed by TransLink than the STM.

What is similar between the two systems is that they both employ modes of transport that are dedicated to providing transit to persons with disabilities. Both systems have a fare structure that caters to seniors and students, and both systems have committees to report on accessibility matters. A notable difference between the two transit systems is the legislation that enforces accessibility standards on public transportation agencies. As has been identified, British Columbia currently has no legislation mandating the provision of accessible public transportation. In comparison, Québec has the Act to Secure Handicapped Persons in the Exercise of their Rights (ASHPER) (Québec Accessible, 2019). ASHPER ensures public transportation providers provide inclusive service and accessibility to persons with disabilities 
(Québec Accessible 2019). Without this type of enforcement, the transportation employed by

TransLink is more equitable than the STM. 


\section{Section Four: Findings and Analysis}

\section{1) How do the cities of Vancouver, Toronto and Montreal define equitability in relation to transit?}

While the definition of equity amongst these cities varies, there are similarities with respect to how each of these transit systems focus on promoting accessibility and equity. The TTC is the only network that has equity defined within its definition of accessibility. TransLink

and the STM each define what accessibility is but appear not to have a definition of equity within the documents reviewed for this MRP. In the Chief Executive Officer's Report, the TTC outlines what Equity and Accessibility means:

The TTC strives to deliver a reliable, safe, clean, and welcoming transit experience for all of its customers, and is committed to making its transit system barrier free and accessible to all. This is at the forefront of TTC's new Corporate Plan 2018-2022. The TTC strongly believes all customers should enjoy the freedom, independence, and flexibility to travel anywhere on its transit system. The TTC measures, for greater accountability, its progress towards achieving its desired outcomes for a more inclusive and accessible transit system that meets the needs of all its customers. This progress includes the TTC's Easier Access Program, which is on track to making all subway stations accessible by 2025 . It also includes the launch of the Family of Services pilot and improved customer service through better on-time service delivery with improved shared rides, and same day bookings to accommodate Family of Service Trips. These initiatives 
will help TTC achieve its vision of a seamless, barrier free transit system that makes Toronto proud. (TTC, Chief Executive Officer's Report, 2019)2.

The corporate policy for the STM discusses accessibility throughout the network's website and policy documents. The STM corporate policy states that the company believes in universal accessibility, and that accessibility is promoted through infrastructure advancements that allow for the universal use of public areas and services (STM, Cooperate universal Accessibility Policy, 2019). Gender inclusion is also an area that is emphasized throughout STM's policies; however, the company's reported statistics on gender inclusion do not depict a diverse workforce as noted in a 2018 diversity study conducted by STM (STM, Diversity, 2019). TransLink does not have a corporate equity policy that is clearly defined. Like Toronto and Montreal, TransLink promotes accessibility. The regional body states that its network is fully accessible (TransLink, Accessible Transit, 2019). In its 2019 Access Strategy, TransLink defines accessibility in relation to destinations (TransLink, 2018 Transit Service Guidelines, 2018). In this definition, the company outlines that accessibility is related to the 'ease' of traveling to and from locations, and accessing goods and or services from a specific area (TransLink, 2018 Transit Service Guidelines, 2018).

\section{2) What types of obstacles do these three cities face in implementing equitable transit} systems?

Funding for improved transit to increase accessibility is similar among the three cities. For Montreal and Toronto, the establishment of their initial subway systems was at a time when structural barriers to implementing accessibility features in the subway stations were not a priority or legislated. In Toronto, the subway stations have hundreds of thousands of passengers

\footnotetext{
${ }^{2}$ Note: the title for this definition states; "Equity/ Accessibility Maters. In relation to equity, the TTC's statements provide the strongest correlation for the network linkages toward equity.
} 
commuting between stations daily and the station cannot close down entirely to improve accessibility (in terms of installing ramps and elevators for mobility impairments), without significant disruptions to transit users' lives. The STM has similar issues as Toronto relating to structural limitations of the system for persons with disabilities. For these reasons, sections of the transit systems are closed for periods of time to enable accessibility technology to be installed, which results in slower implementation process.

Lack of funding for projects is another issue that is common amongst the three transit systems. Barrier reduction - in terms of structural improvements via installation of elevators, ramps and other assistive improvements - costs millions of dollars and takes time. In Toronto, the approval of funding from city council is an ongoing issue. There are many impasses and delays when the municipality votes to legislate on improvements and additions relating to transportation. This is the same for Montreal and Vancouver to an extent. However, as noted in Section One, TransLink, unlike Montreal and Toronto, has the power to raise its own funds through taxation. However, given this power, transportation projects are still very expensive, costing millions and or billions of dollars. Raising taxes is often a last resort as this measure is always unpopular.

\section{3) What current strategies have been taken to ensure more equitable transportation in}

\section{these three cities}

Each of the cities employs similar strategies with respect to equity, in relation to accessibility. Table 8: The Equity Comparison Chart demonstrates these accessible comparisons. For example, each city has more than one accessible mode of transportation. Table 8 shows a comparative overview of the equity polices employed by the TTC, STM and TransLink. Numerically, the chart depicts in some categories the number of policies employed. 


\begin{tabular}{|c|c|c|c|c|c|c|}
\hline $\begin{array}{l}\text { Equity } \\
\text { Policy } \\
\text { Categories }\end{array}$ & $\begin{array}{l}\text { Accessible } \\
\text { Mode of } \\
\text { transportation }\end{array}$ & $\begin{array}{l}\text { Equitable } \\
\text { fare } \\
\text { structure }\end{array}$ & $\begin{array}{l}\text { Barrier } \\
\text { reduction }\end{array}$ & $\begin{array}{l}\text { Equity } \\
\text { Advisory } \\
\text { Committee }\end{array}$ & $\begin{array}{l}\text { Equity/Accessibility } \\
\text { legislation/ policies }\end{array}$ & $\begin{array}{l}\text { Equity } \\
\text { Programs }\end{array}$ \\
\hline \multicolumn{7}{|c|}{ Vancouver: TransLink } \\
\hline $\begin{array}{l}\text { Vertical } \\
\text { Equity } \\
\text { Policies }\end{array}$ & Yes & 5 & Yes & $\begin{array}{l}2 \\
\text { committees }\end{array}$ & No legislation & $\begin{array}{l}4 \\
\text { programs }\end{array}$ \\
\hline $\begin{array}{l}\text { Horizontal } \\
\text { Equity } \\
\text { Policies }\end{array}$ & & 2 & & & & 1 program \\
\hline \multicolumn{7}{|c|}{ Toronto: TTC } \\
\hline $\begin{array}{l}\text { Vertical } \\
\text { Equity } \\
\text { Policies }\end{array}$ & yes & 4 & Yes & $\begin{array}{l}1 \\
\text { committee }\end{array}$ & $\begin{array}{l}\text { Legislation/ } \\
\text { accessibility } \\
\text { enforced on public } \\
\text { and private } \\
\text { transportation } \\
\text { systems }\end{array}$ & 1 program \\
\hline $\begin{array}{l}\text { Horizontal } \\
\text { Equity } \\
\text { Policies } \\
\end{array}$ & & 2 & & & & \\
\hline \multicolumn{7}{|c|}{ Montreal: STM } \\
\hline $\begin{array}{l}\text { Vertical } \\
\text { Equity } \\
\text { Policies }\end{array}$ & yes & 2 & yes & $\begin{array}{l}1 \\
\text { committee }\end{array}$ & $\begin{array}{l}\text { Legislation - only } \\
\text { enforces } \\
\text { accessibility on } \\
\text { public transportation } \\
\text { companies }\end{array}$ & 1 program \\
\hline $\begin{array}{l}\text { Horizontal } \\
\text { Equity } \\
\text { Policies }\end{array}$ & & 2 & & & & \\
\hline
\end{tabular}




\section{Conclusions}

This Major Research Paper compared Vancouver's TransLink transportation equity policies to Toronto's TTC system and Vancouver's TransLink system. Vancouver was chosen because the research uncovered that it includes a range of equity transit policies that are quite progressive. TransLink is a consortium of public transportation companies; however, Toronto and Montreal's systems are overseen by a number of municipalities. In adhering to the comparative municipal aims of the study, only transportation systems, fares and policies employed in Vancouver's Zone One were analyzed (see Appendix B: TransLink Zone Fare Map, for details). In addition, the MRP was limited to studying transportation structures within the municipalities of Toronto and Montreal. The MRP also offered concise overviews of when the move toward incorporating equity, in terms of accessibility, began in each respective transit system.

A distinguishing factor between the three cities is that two of the three cities, Toronto and Montreal, have provincial legislation that mandates public transportation accessibility. In Ontario, the Accessibility for Ontarians with Disability Act (AODA) mandates both private and public transportation companies to introduce accessibility features within their transit networks. Yet, Vancouver has been able to advance and employ more equity policies relating to accessibility within its network without provincial legislation mandating that public and private transportation companies employ accessibility in their networks. This is one of the reasons why Vancouver has the most equitable transportation network. Other aspects relate to the number of the committees and equity programs that TransLink employs, which helps TransLink to continue to support and promote equity and accessibility within its transit system. 
Much knowledge has been gained in the course of researching and writing this MRP; however, due to the scope and time limits of undertaking this type of scholarship, some potential areas of inquiry were not followed. Ample opportunity exists for future scholars to undertake a similar study but on a more regional level that would offer a rich and fruitful opportunity to explore the equity and accessibility at a regional level. A second option would be to compare the transit systems in Montreal, Toronto, or Vancouver to similar systems in another country. Clearly, significant opportunities exist to explore the accessibility and equity of transit policies in multi-governance approaches that would help to make transit more accessible for a greater number of citizens. 


\section{Appendices}

Appendix A: 2019-2013 TTC Multi- Year Accessibility Plan

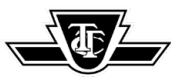

For Action

\section{9-2023 TTC Multi-Year Accessibility Plan}

Date: May 8, 2019

To: $\quad$ TTC Board

From: Chief Customer Officer

\section{Summary}

TTC has a strong organizational commitment to making Toronto's transit system accessible. Following up on the TTC's 2014-2018 TTC Multi-Year Accessibility Plan, the new 2019-2023 TTC Multi-Year Accessibility Plan will guide system-wide accessibility improvements over the next five years that will provide universal benefits to the millions of customers whosuse who TTC annually, in support of TTC's Corporate Plan.

The previous 2014-2018 Plan contained 41 objectives to improve and expand TTC's accessible transit services. Of these:

$\checkmark 32$ objectives (78\%) were successfully completed between 2014 and 2018;

- one objective will be completed in 2019 , as planned, and one objective was superseded by new initiatives and is no longer proceeding; and

$X$ seven objectives are in-progress and will be completed within the term of the 2019-2023 TTC Multi-Year Accessibility Plan.

TTC's numerous accessibility achievements over the past five years, all of which improved and modernized transit service for people with disabilities and seniors, include:

- retrofitting seven subway stations with elevators and accessibility features;

- opening six new accessible subway stations on the Line 1 Extension to Vaughan;

- trialling platform edge tile replacements to reduce the gap between trains and subway platforms;

- deploying low-floor accessible streetcars on four routes;

- upgrading over 400 transit stops to modern accessible design standards in 2018;

- retiring the last lift-equipped TTC buses; all TTC buses are now low-floor;

- installing blue priority seating areas and signage on all TTC vehicles;

- revising and expanding Wheel-Trans eligibility;

- launching Community Bus, Family of Services, and Travel Training initiatives as well as the Fair Pass Discount Program for customers with low income;

- constructing Access Hubs at two bus loops;

- introducing the Please Offer Me A Seat (POMAS) campaign; 


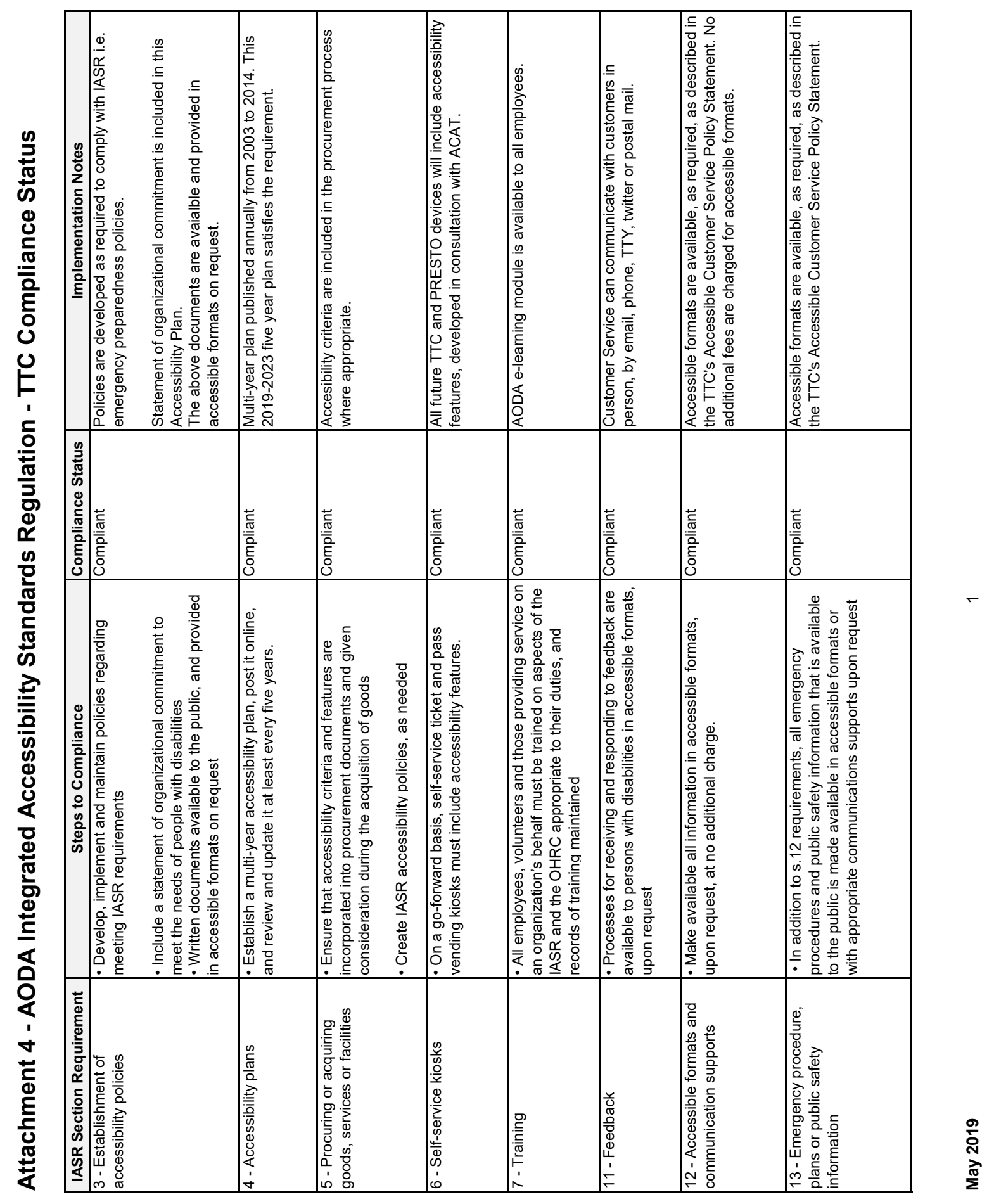




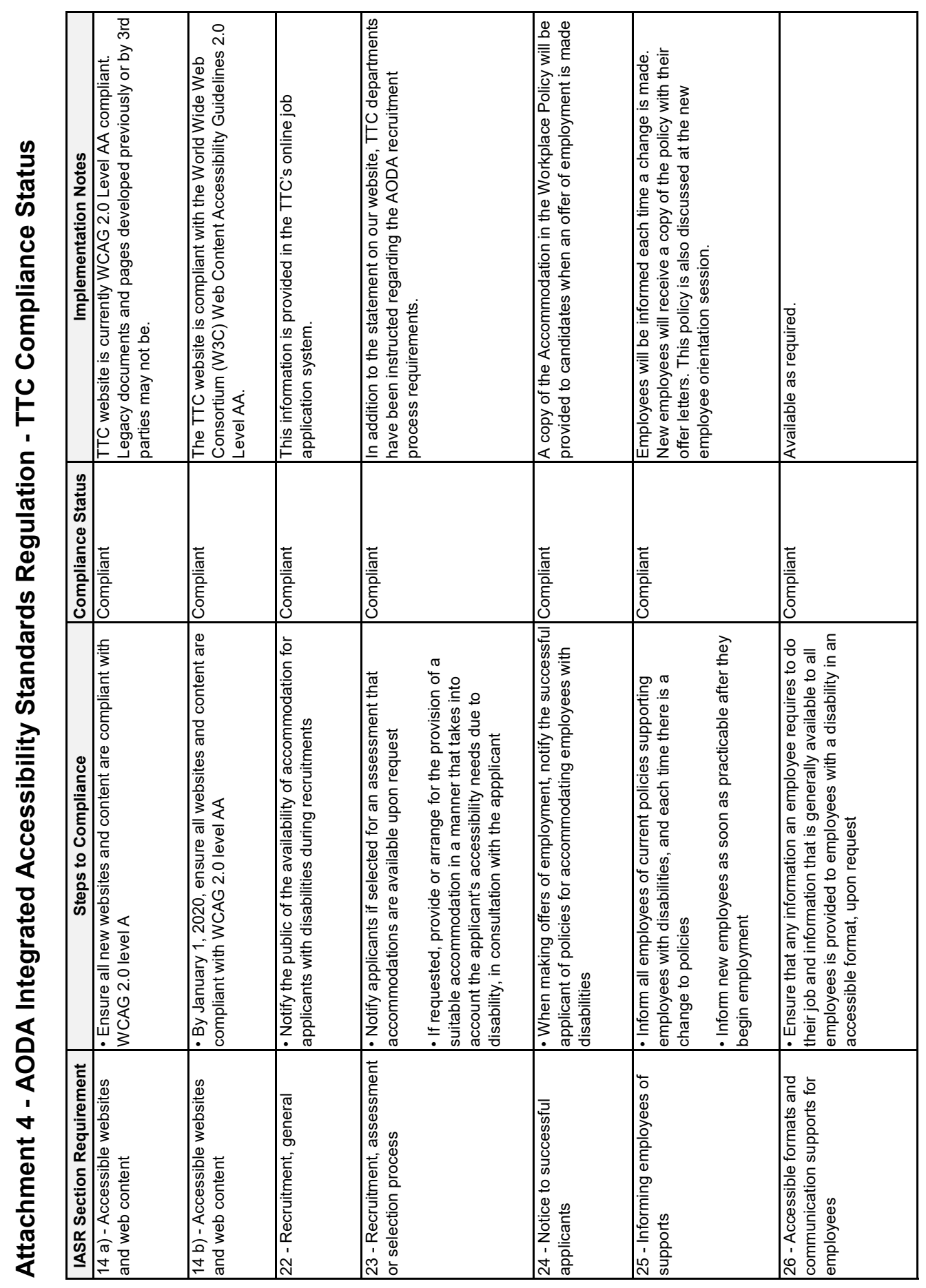

$N$

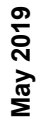




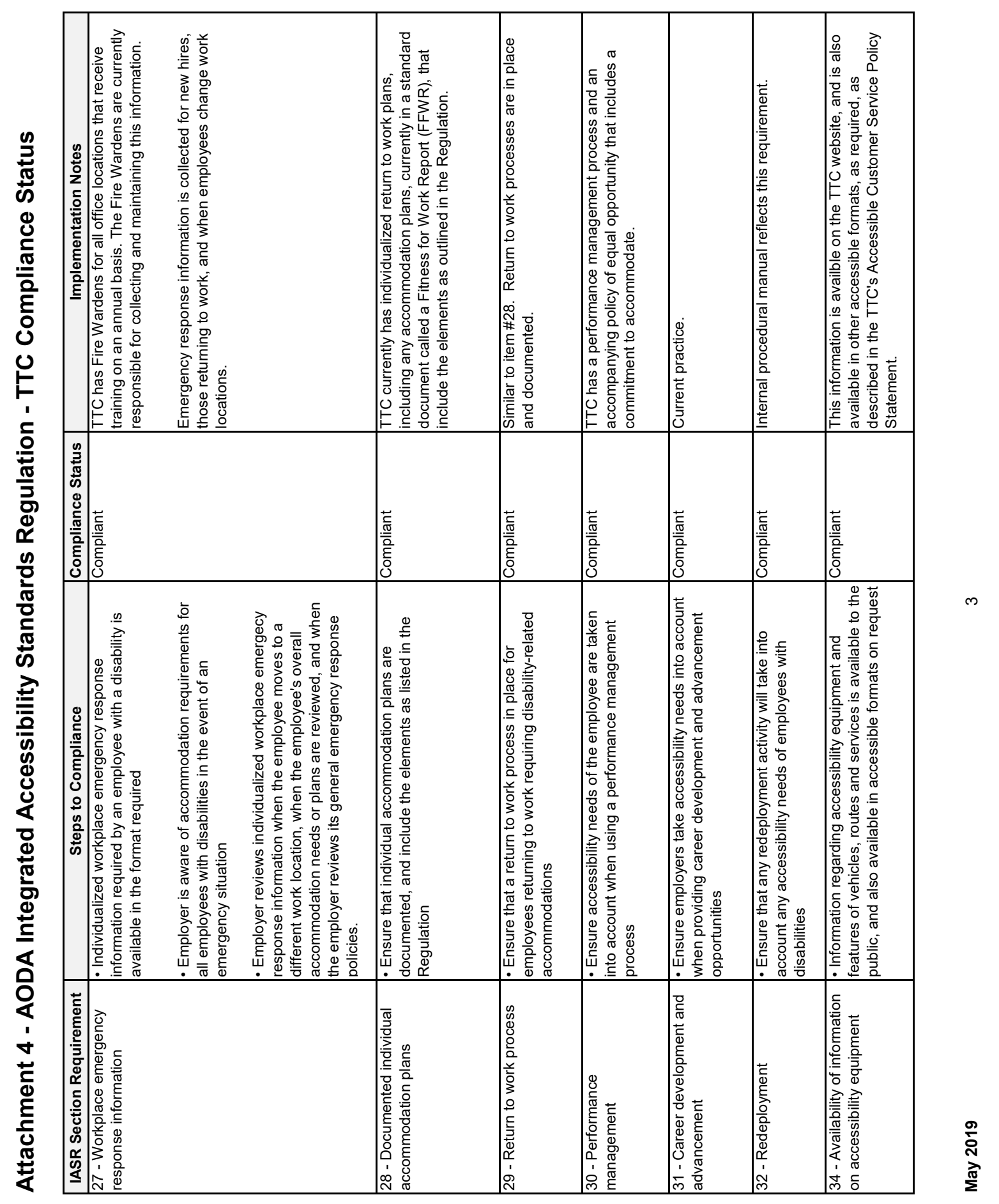




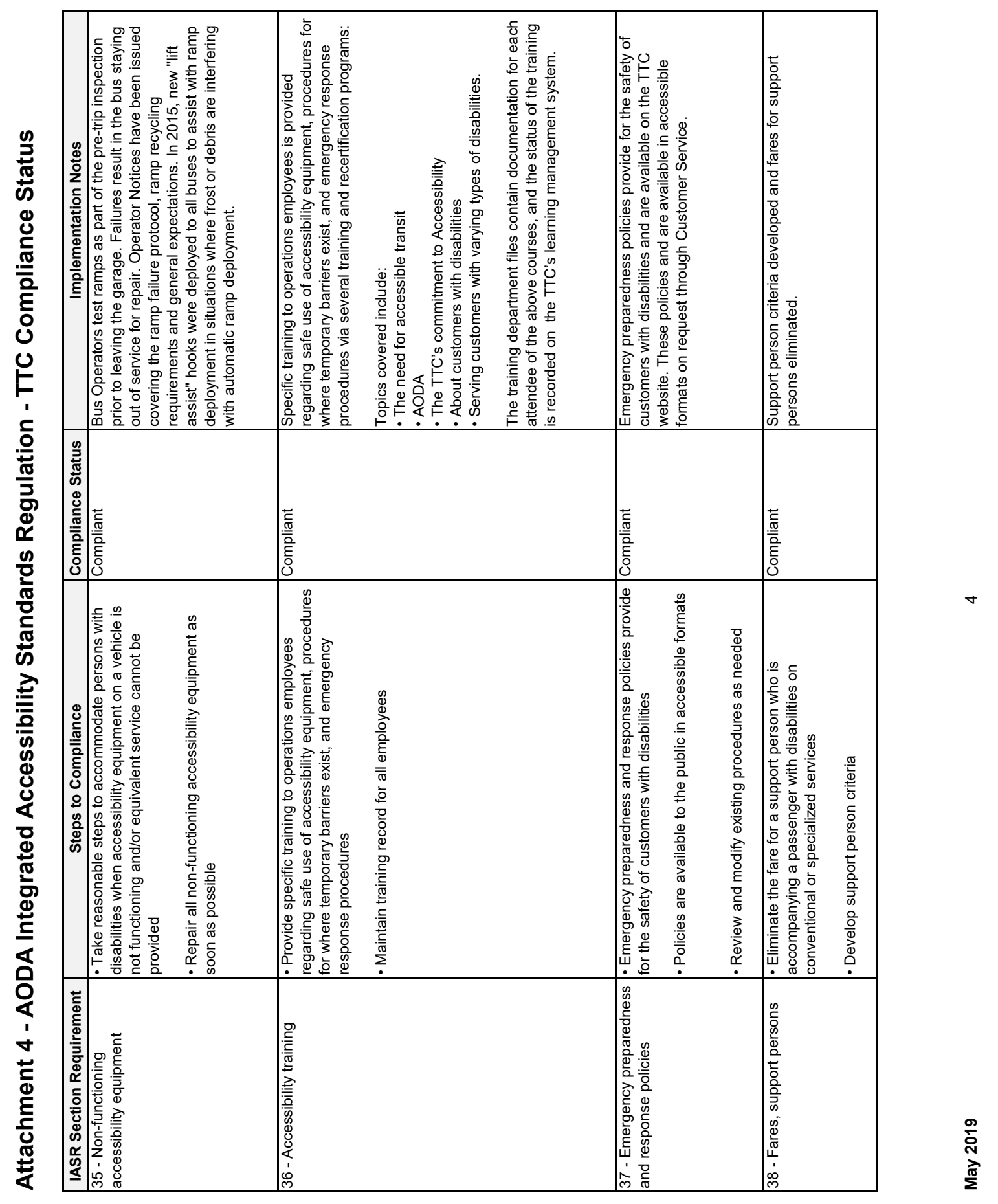




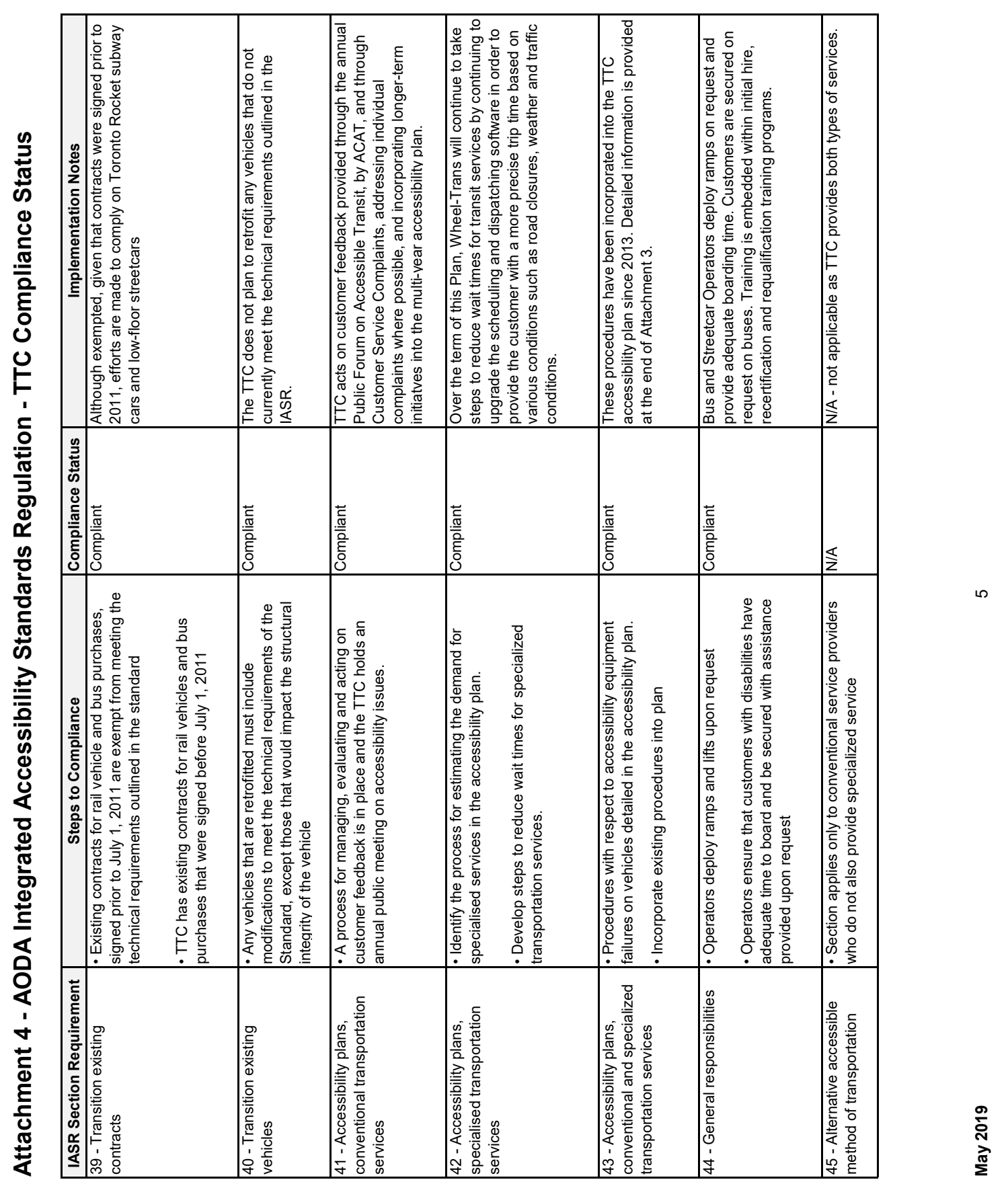




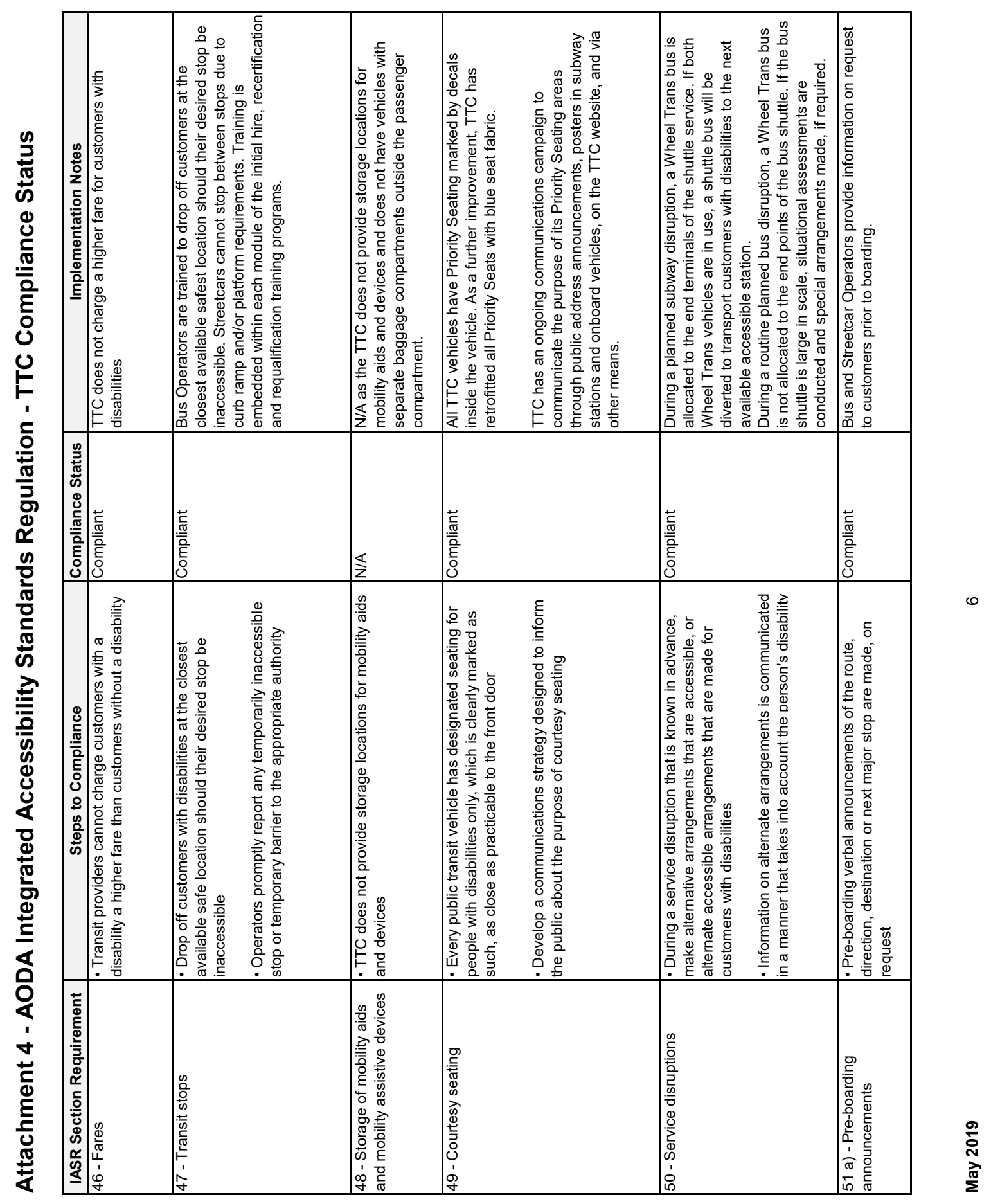




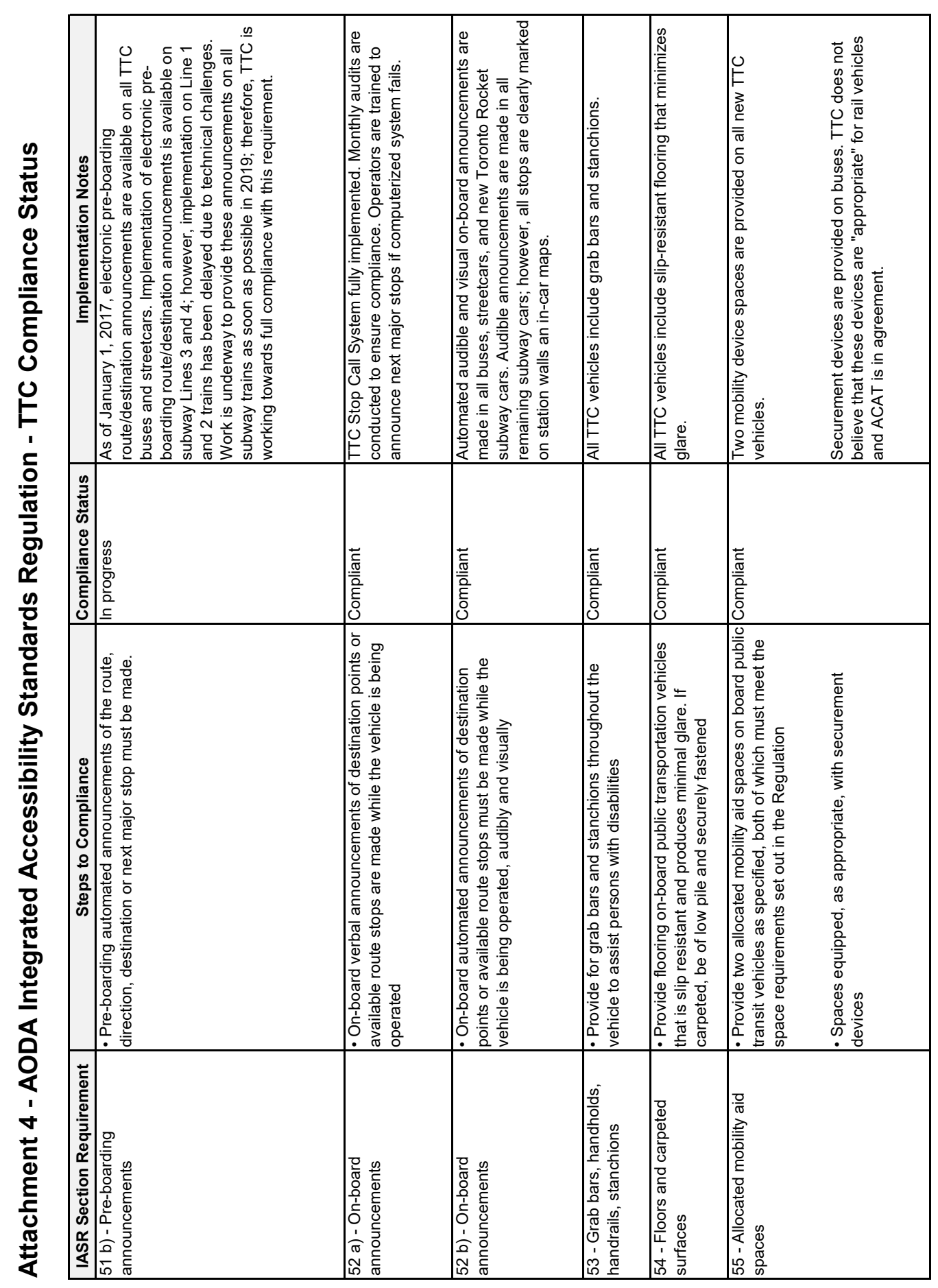

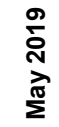




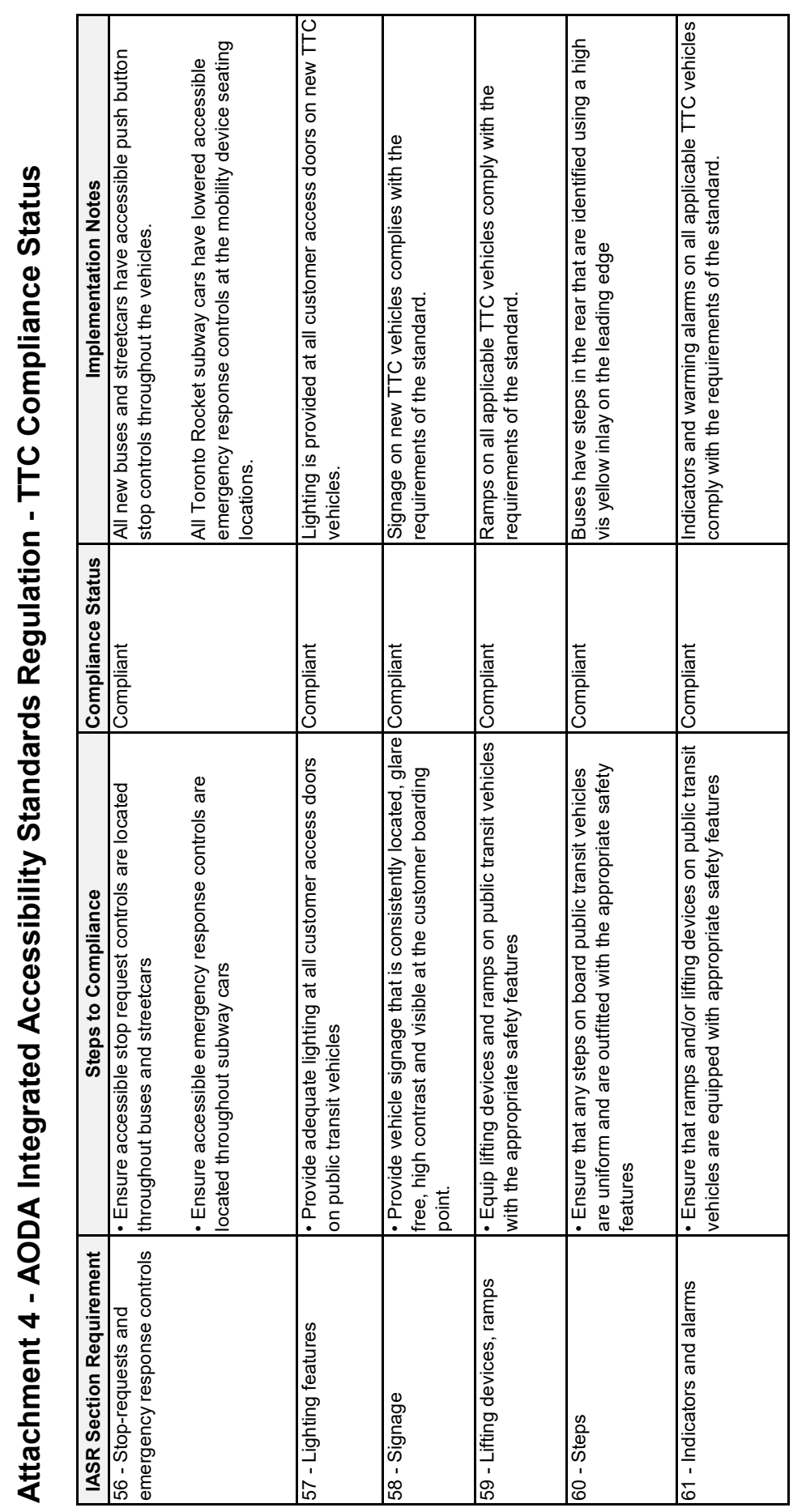

$\infty$

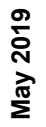




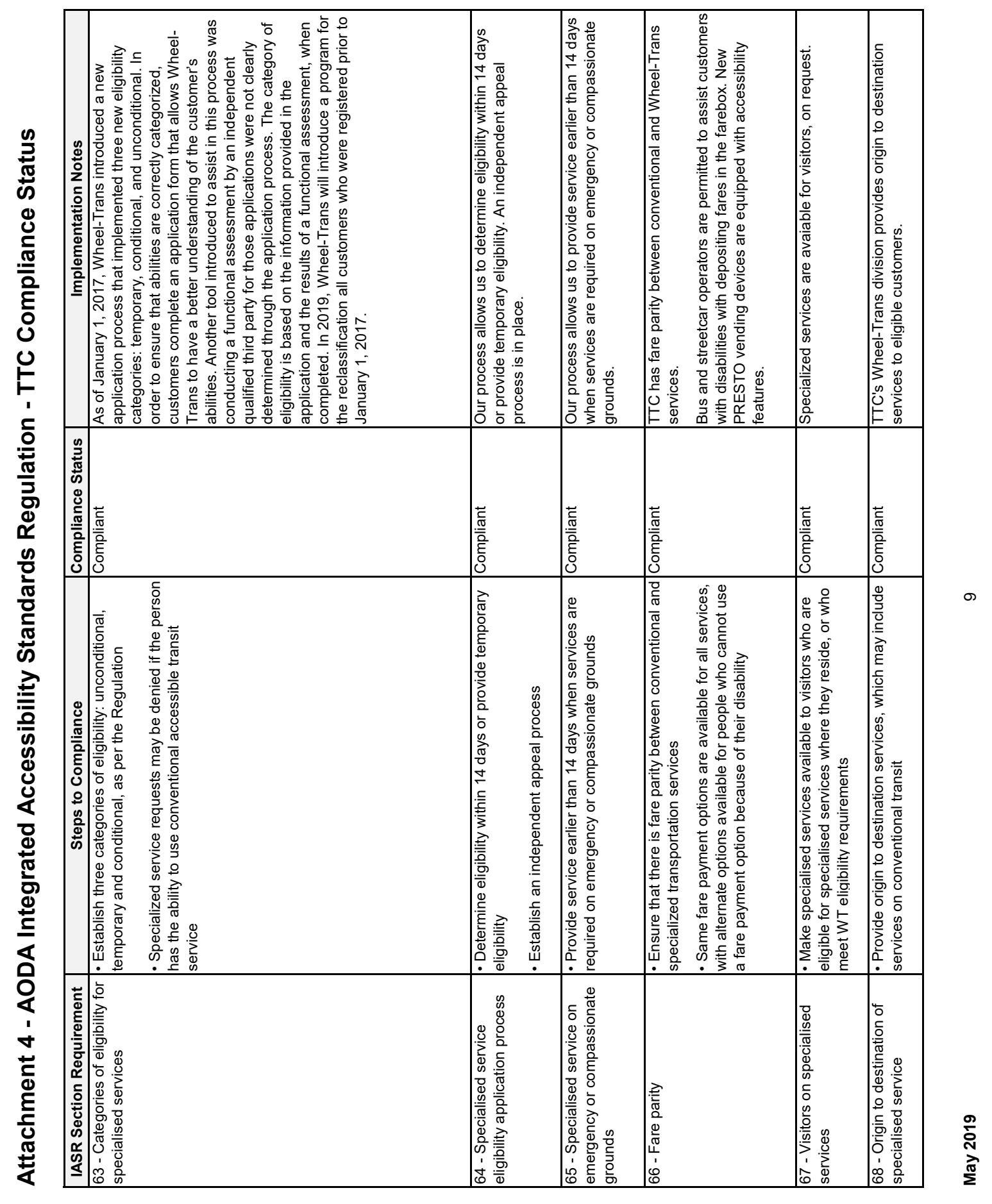




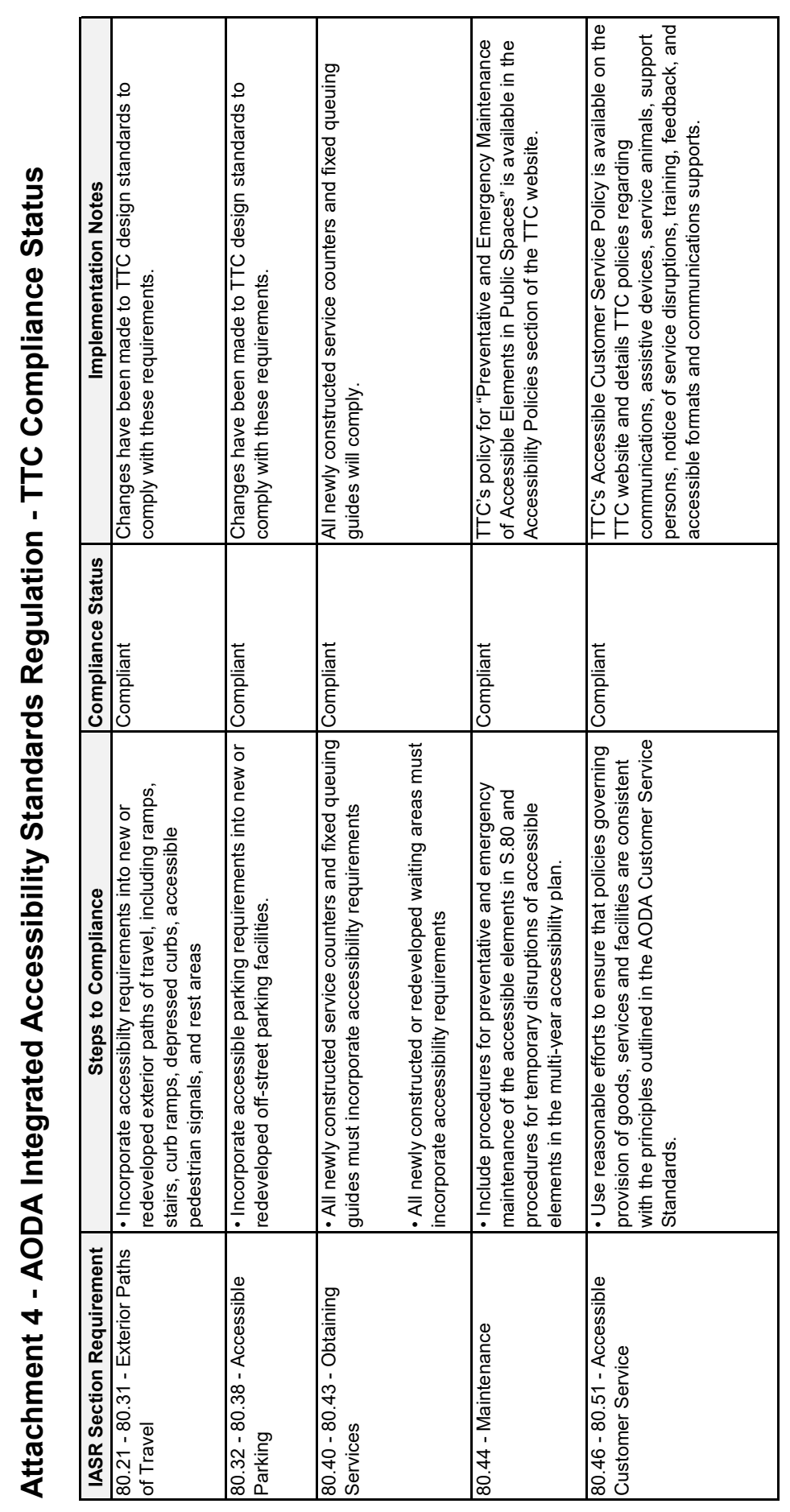




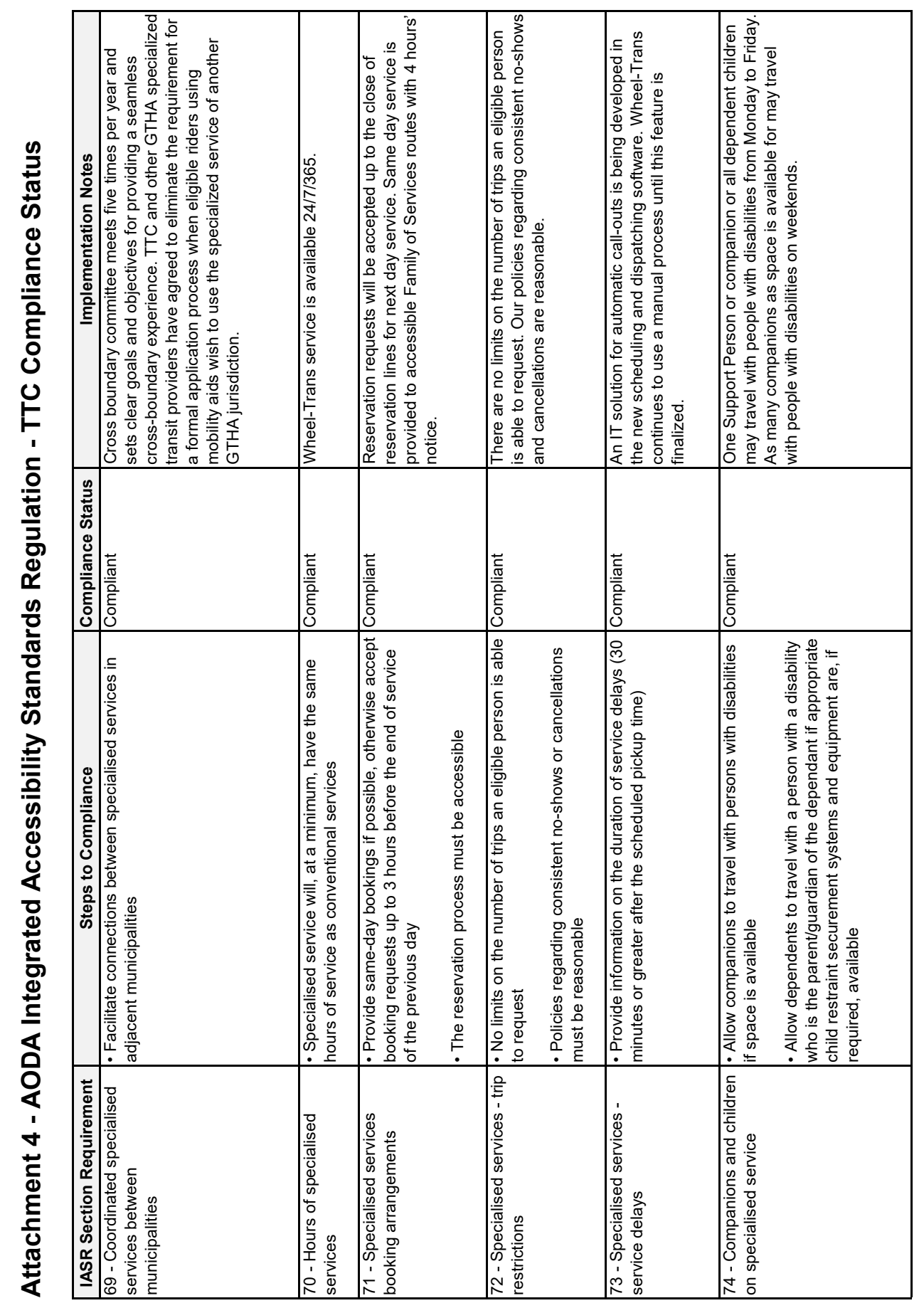

으

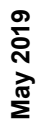


Appendix B: TransLink Zone Fare Map

\section{Fare Zone Map}

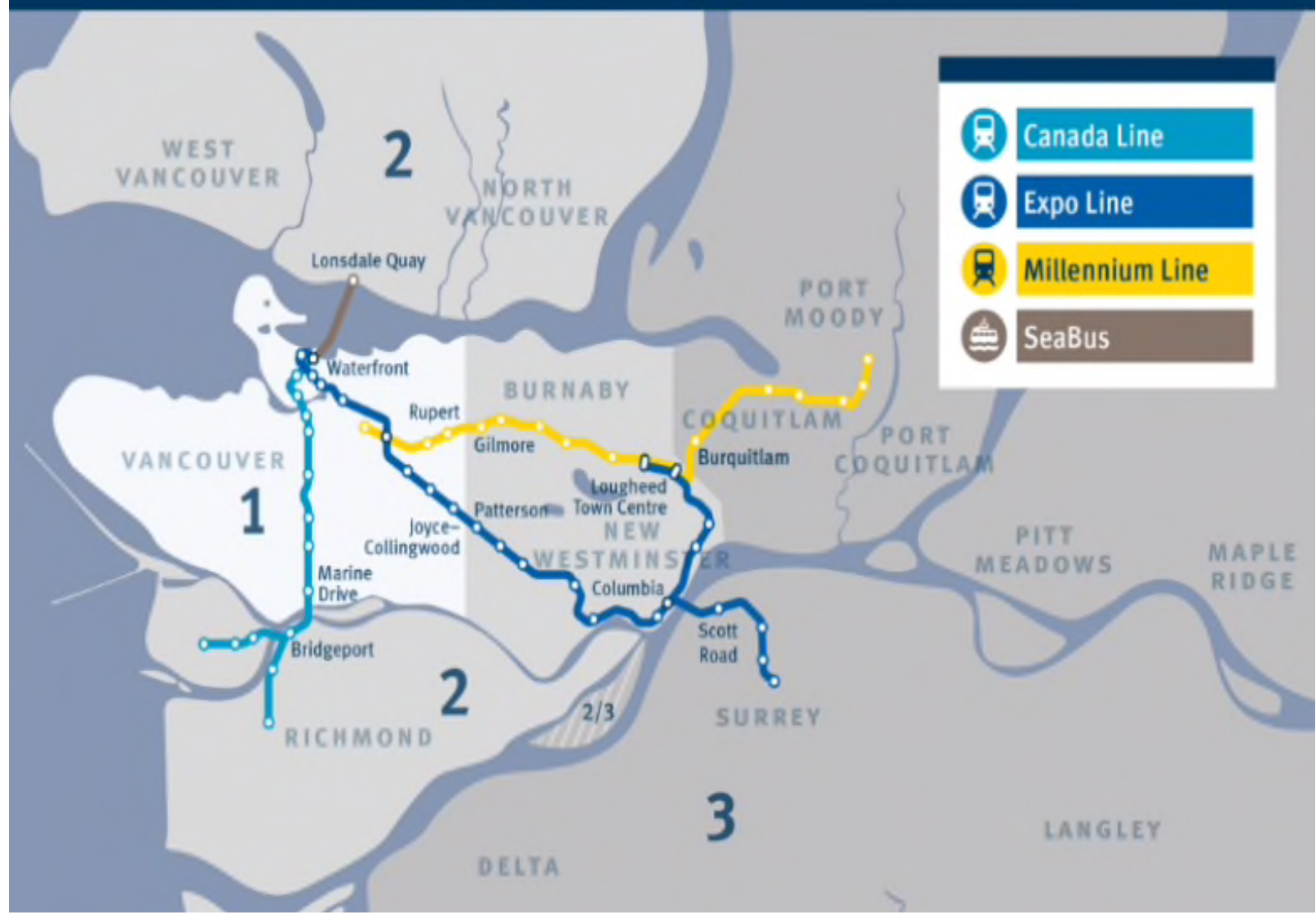




\section{References}

Accessibility Service Canada. (2019). British Columbia Accessibility Act. Retrieved, July 22, from https://accessontario.com/british-columbia-accessibility-act/

Aery, A. (2016). Transit can lead the way for an accessible Toronto. Retrieved November 20, 2018, from http://www.wellesleyinstitute.com/health/transit-can-lead-the-way-for-anaccessible-Toronto/

Bornman, J. (2003). The World Health Organization's terminology and classification: application to severe disability. Disability and Rehabilitation, 3, 182-188. doi: doi.org/10.1080/09638280410001665218

Bureau International des Expositions. (2019). About World Expos. Retrieved, July 22, 2019, from https://www.bie-paris.org/site/en/about-world-expos

Burns, K., Gordon, G. (2010). Analyzing the impact of disability legislation in Canada and the United States. Journal of Disability Policy Studies, 24(1), 205-218. doi $10.1177 / 1044207309344562$

Camporeale, R., Caggiani, L., Fonzone, A., Ottomanelli, M. (2016). Quantifying the impacts of horizontal and vertical equity in transit route planning. Transportation Planning Technology, 40(1), 28-44. doi 10.1080/03081060.2016.1238569

Cui, B., Boisjoly, G., El-Geneidy, A., Levinson, D. (2019). Accessibility and the journey to work through the lens of equity. Journal of Transport Geography, 74, 269-277. doi 10.1016/j.jtrangeo.2018.12.003

City of Toronto. (2019). Transit Discount, Fair Pass Discount Program. Retrieved, June 15, 2019, from https://www.toronto.ca/community-people/employment-socialsupport/support-for-people-in-financial-need/assistance-through-ontario-works/transitdiscount/

Denters, B., Mossberger, K. (2006). Building blocks for a methodology for comparative urban political research. Urban Affairs Review, 41(4), 550-571. doi $10.1177 / 1078087405282607$

Derrible, S. (2012). Reviewing and assessing the Toronto metro system. Canadian Journal of Civil Engineering, 39, 154-162. doi 10.1139/111-118

Filey, M. (1996). The TTC Story: The first seventy-five years. Toronto: Dundurn Press.

Gilbert, D., Poitras, C. (2015). 'Subways are not outdated:' debating the Montreal Metro, 194060. The Journal of Transport History, 36(2), 209-227. doi: 10.7227/TJTH.36.2.5

Government of British Columbia. (2019). BC bus pass for seniors and others. Retrieved, July 10, 2019, from https://www2.gov.bc.ca/gov/content/transportation/passenger-travel/busestaxis-limos/bus-pass/seniors 
Hertel, S., Keil, R., Collens, M. (2016). Next stop equity: routes to fairer transit access in the Greater Toronto and Hamilton Area. Retrieved from https://city.apps01.yorku.ca//wpcontent/uploads/2016/02/Transit-Equity_Reduced_020216.pdf

Hulchanski, D. (2006). The three cities within Toronto: Income polarization among Toronto's neighbourhoods, 1970-2005. Toronto: Cities Centre University of Toronto

J. McMillen (personal communication, July 9, 2019).

Legislative Assembly of British Columbia. (2018). Bill M 219-2018: British Columbia Accessibility Act. Retrieved, July 22, 2019, from https://www.leg.bc.ca/parliamentarybusiness/legislation-debates-proceedings/41st-parliament/3rd-session/bills/firstreading/m219-1

Meligrana, J. (1999). Toward regional transportation governance: A case study of Greater Vancouver. Transportation, 26 (4), 359-398. doi 10.1023/A:1005231322989

Office des Personnes Handicapées. (2019). Better understanding in 3 minutes. Retrieved, July 10, 2019, from https://www.ophq.gouv.qc.ca/publications/cyberbulletins-deloffice/express-o/volume-9-numero-5-17-septembre-2015/mieuxcomprendre/limportance-des-mots.html

Office des Personnes Handicapées. (2019). Publications. Retrieved, July 10, 2019, from https://www.ophq.gouv.qc.ca/publications/publications-in-english.html

PRESTO. (2018). Save even more with PRESTO. Retrieved, June 10, 2019, from https://www.prestocard.ca/en/about/discounted-double-fare

Radforth, I. (2015). Playful crowds and the 1998 Toronto Street Railway strikes. Labour/Le Travail, 76, 133-164. Retrieved from https://www.jstor.org/stable/44123079?seq=1\&cid=pdfreference\#references_tab_contents

Roberts, C. (2006). Radio frequency identification (RFID). Computers \& Security, 25(1), 18-26. doi $10.1016 /$ j.cose. 2005.12 .003

Sinclair. (1891). The Toronto street railway. The Quarterly Journal of Economics, 6, 98-105. Retrieved from https://www-jstororg.ezproxy.lib.ryerson.ca/stable/pdf/1882166.pdf?refreqid=excelsior\%3A2d5feec042ab $1681 \mathrm{f} 4 \mathrm{f} 48 \mathrm{c} 8 \mathrm{~d} 43 \mathrm{c} 72 \mathrm{cf3}$

Société de transport de Montréal. (2019). 2019 Budget. Retrieved, July 10, 2019, from http:/www.stm.info/sites/default/files/pdf/fr/budget2019.pdf

Société de transport de Montréal. (2019). Bus history. Retrieved, July 10, 2019, from http://www.stm.info/en/about/discover_the_stm_its_history/history/bus-history 
Société de transport de Montréal. (2019). Board of directors. Retrieved, July 10, 2019, from http://www.stm.info/en/about/corporate-governance/board-directors

Société de transport de Montréal. (2019). Diversity. Retrieved, July 10, 2019, from http://www.stm.info/en/about/financial_and_corporate_information/diversity

Société de transport de Montréal. (2019). Fares. Retrieved, July 10, 2019, from http://www.stm.info/en/info/fares

Société de transport de Montréal. (2019). Group fares. Retrieved, July 10, 2019, from http://www.stm.info/en/info/fares/transit-fares/group

Société de transport de Montréal. (2019). OPUS reduced fare - students. Retrieved, July 10, 2019, from http://www.stm.info/en/info/fares/opus-cards-and-other-fare-media/opusreduced-fare-students

Société de transport de Montréal. (2019). Paratransit history. Retrieved, July 10, 2010, from http://www.stm.info/en/about/discover_the_stm_its_history/history/paratransit-history

Société de transport de Montréal. (2019). Using paratransit. Retrieved, July 10, 2019, from http://www.stm.info/en/paratransit/using-paratransit

Société de transport de Montréal. (2019). What is paratransit. Retrieved, July 10, 2019, from http://www.stm.info/en/paratransit/about-paratransit/what-paratransit

Société de transport de Montréal. (2019). Transit fares. Retrieved, July 10, 2019, from http://www.stm.info/en/info/fares/transit-fares

Slater, C. (1997). General motors and the demise of streetcars. Transportation Quarterly, 51 (3), 45-66. Retrieved from http://cliffslater.com/TQOrigin.pdf

Spinal Cord Injury BC. (2019). Accessible transportation in BC: history of many victories. Retrieved, July 22, from https://sci-bc.ca/accessible-transportation-in-bc-a-history-ofmany-victories/

Spinal Cord Injury BC. (2019). How accessible is Vancouver's transit system, really? Retrieved, July 22, 2019, from https://sci-bc.ca/how-accessible-is-vancouvers-transit-system-really/

Toronto Transit Commission. (2019). Accessibility, elevators and escalators. June 10, 2019 fromhttps://www.ttc.ca/TTC_Accessibility/Easier_access_on_the_TTC/Elevators_and_es calators.jsp

Toronto Transit Commission. (2017). 2017 Accessibility plan status report. Retrieved from https://www.ttc.ca/About the_TTC/Commission_reports_and_information/Commission meetings/2017/April_20/Reports/9_2017_Accessibility_Plan_Status_Report_BR\%2018 $\overline{3}$ 89.pdf 
City of Toronto. (2019). Toronto Transit Commission budget 2019. Retrieved July 10, 2019, from https://www.toronto.ca/city-government/budget-finances/city-budget/notes-reportsand-presentations/toronto-transit-commission-budget/

Toronto Transit Commission. (2019). General information. Retrieved, June 10, 2019 from https://www.ttc.ca/Routes/General_Information/General_Information.jsp

Toronto Transit Commission. (2019). 2019-2013 Multi-year accessibility plan. Retrieved from http://ttc.ca/About_the_TTC/Commission_reports_and_information/Commission_meetin gs/2019/May_8/Reports/6_2019-2023_TTC_Multiyear_Accessibility_Plan.pdf

Toronto Transit Commission (2018). 2017 Operating statistics. Retrieved, June 10, 2019 from https://www.ttc.ca/About_the_TTC/Operating_Statistics/2017/section_one.jsp

Toronto Transit Commission. (2018). Ridership growth strategy 2018-2022. Retrieved, June 10, 2019, from

http://ttc.ca/About_the_TTC/Commission_reports_and_information/Commission_meetin gs/2018/January__5/Reports/2_Ridership_Growth_Strategy_2018-2022_Presentation.pdf

Toronto Transit Commission (1980). Toronto Transit Commission: Annual Report 1980.

Retrieved from

https://www.ttc.ca/Coupler/Annual_Reports/1980\%20Annual\%20Report.pdf

Toronto Transit Commission. (2019). TTC, section One, milestones. Retried, June 10, 2019, from Toronto https://www.ttc.ca/About_the_TTC/History/Milestones.jsp

Toronto Transit Commission. (2019). Wheel trans eligibility application. Retrieved, July 10, 2019, from https://www.ttc.ca/PDF/Wheel-Trans/WheelTrans\%20Eligibility\%20Application.pdf

TransLink. (2019). Accessible transit. Retrieved, July 22, 2019, from https://www.translink.ca/Rider-Guide/Accessible-Transit.aspx

TransLink. (2019). CNIB ID compass card. Retrieved, July 22, from https://www.translink.ca/Rider-Guide/Accessible-Transit/CNIB-ID-Compass-Card.aspx

TransLink. (2019). Compass card. Retrieved, July 22, 2019, from https://www.translink.ca/Fares-and-Passes/Compass-Card.aspx

TransLink. (2019). Corporate overview. Retrieved, July 30, from https://www.translink.ca/About-Us/Corporate-Overview.aspx

TransLink. (2019). Fare pricing. Retrieved, July 22, 2019, from https://www.translink.ca/Faresand-Passes/Fare-Pricing.aspx

TransLink. (2019). Governance model. Retrieved, July 22, 2019, from https://www.translink.ca/About-Us/Governance-and-Board/Governance-Model.aspx 
TransLink. (2019). HandyDart. Retrieved, July 22, 2019, from https://www.translink.ca/RiderGuide/Accessible-Transit/HandyDART.aspx

TransLink. (2013). HandyDart \& HandyCard application form. Retrieved, July 22, 2019, from https://www.translink.ca/-

/media/Documents/rider_guide/access_transit/handydart_card/HandyDART\%20Card\%2 0Application\%20Form.pdf

TransLink. (2019). HandyDart users' advisory committee. Retrieved, July 22, 2019, from https://www.translink.ca/Rider-Guide/Accessible-Transit/Access-Transit/HandyDARTAdvisory-Committee.aspx

TransLink. (2019). History of the sky train. Retrieved, July 22, 2019, from https://www.translink.ca/About-Us/Corporate-Overview/OperatingCompanies/BCRTC/History-of-SkyTrain.aspx

TransLink. (2017). Regional transportation snapshot. Retrieved, July 22, 2019, from https://www.translink.ca/-

/media/Documents/plans_and_projects/accountability_centre/TransLink\%20Regional\%2 0Snapshot\%20Report.pdf

TransLink, (2019). TransLink sees record ridership in 2017. Retrieved, July 22, from https://www.translink.ca/About-Us/Media/2018/February/TransLink-sees-recordridership-in-2017.aspx

TransLink. (2019). TravelSmart. Retrieved, July 22, from https://www.translink.ca/RiderGuide/TravelSmart.aspx

TransLink. (2019). Universal fare gate access program. Retrieved, July 22, from, https://www.translink.ca/Rider-Guide/Accessible-Transit/Universal-Fare-Gate-AccessProgram.aspx

TransLink. (2019). Users' Advisory committee. Retrieved, July 22, 2019, from https://www.translink.ca/Rider-Guide/Accessible-Transit/Access-Transit/UsersAdvisory-Committee.aspx

TransLink. (2018). 2018 year-end financial and performance report. Retrieved, July 22, 2019, from https://www.translink.ca//media/Documents/about_translink/corporate_overview/corporate_reports/quarterly_repo rts/2018/Year_End_2018_Finance_and_Performance_Report_15-32018.pdf?la $=$ en\&hash $=$ A91F0FEBD24C455D5E7C8142BB5122B7CA7B5D6F

Varghese, S. (2018, January 12). The cold hard truth about Toronto's transport network. CityMetric. Retrieved from https://www.citymetric.com/transport/cold-hard-truth-abouttorontos-transport-network-3597 
Veilleux, D. (1996). Buses, tramways, and monopolies: The introduction of motor vehicles into Montreal's public transport network. Michigan Historical Review, 22(2), 103-126. doi: $10.2307 / 20173588$

Wales, T. (2008). The road less travelled: TransLink's Improbable journey from 1999 to 2008. Retrieved from https://www.translink.ca//media/Documents/about_translink/corporate_overview/corporate_reports/history/translin k_history_nov_2008.pdf 